\title{
Integration of High Temperature Gas-cooled Reactor Technology with Oil Sands Processes
}

Greg Gibbs

Soheil Asgarpour

October 2011

The INL is a

U.S. Department of Energy

National Laboratory

operated by

Battelle Energy Alliance

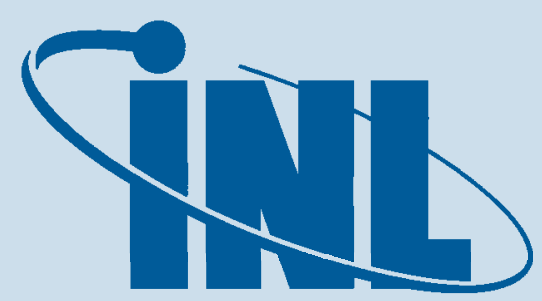

Idaho National Laboratory

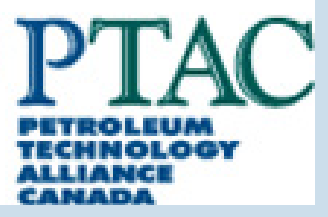

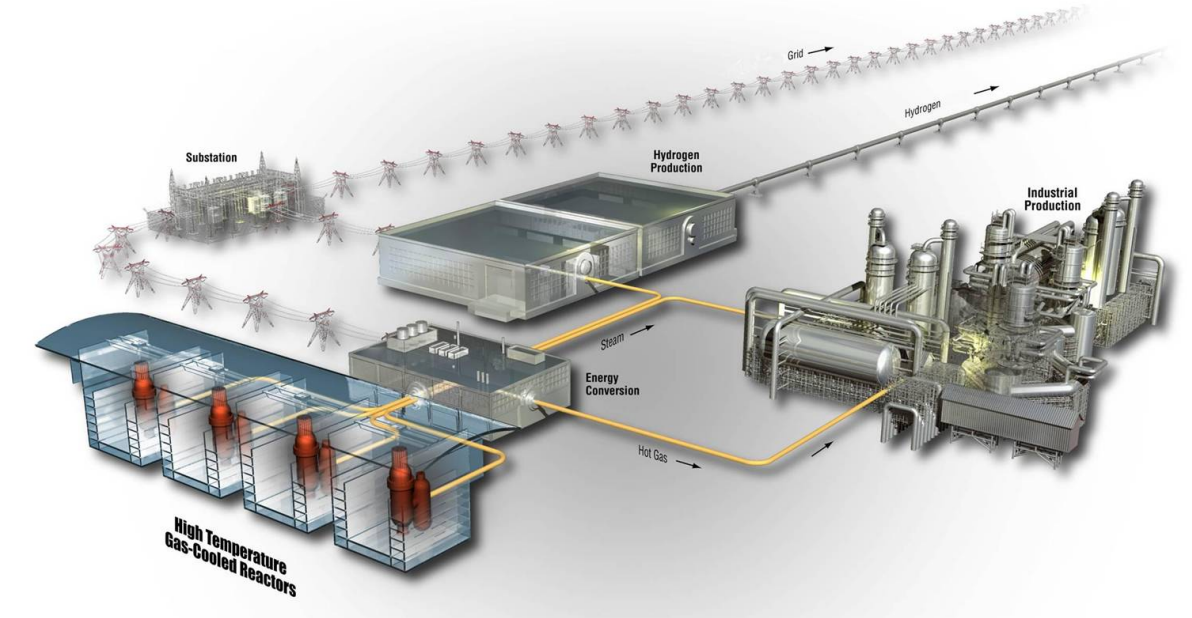




\section{DISCLAIMER}

This information was prepared as an account of work sponsored by an agency of the U.S. Government. Neither the U.S. Government nor any agency thereof, nor any of their employees, makes any warranty, expressed or implied, or assumes any legal liability or responsibility for the accuracy, completeness, or usefulness, of any information, apparatus, product, or process disclosed, or represents that its use would not infringe privately owned rights. References herein to any specific commercial product, process, or service by trade name, trade mark, manufacturer, or otherwise, does not necessarily constitute or imply its endorsement, recommendation, or favoring by the U.S. Government or any agency thereof. The views and opinions of authors expressed herein do not necessarily state or reflect those of the U.S. Government or any agency thereof. 


\section{Integration of High Temperature Gas-cooled Reactor Technology with Oil Sands Processes}

October 2011

Idaho National Laboratory

Next Generation Nuclear Plant Project

Idaho Falls, Idaho 83415

http://www.inl.gov

Prepared for the

U.S. Department of Energy

Office of Nuclear Energy

Under DOE Idaho Operations Office

Contract DE-AC07-05ID14517 

Next Generation Nuclear Plant Project

Integration of High Temperature Gas-cooled Reactor Technology with Oil Sands Processes

INL/EXT-11-23239

October 2011

Approved by:

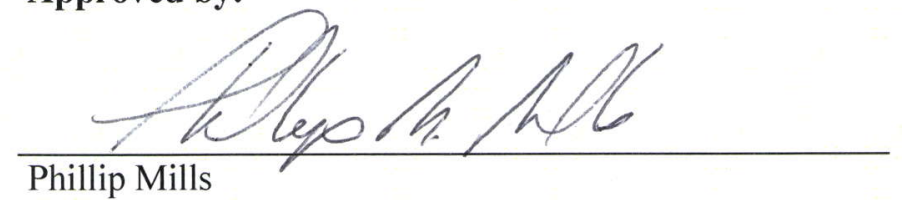

NGNP Project Engineering Director

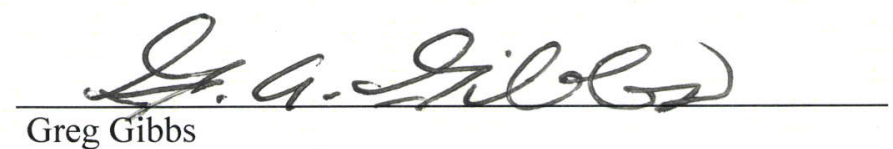

NGNP Project Director
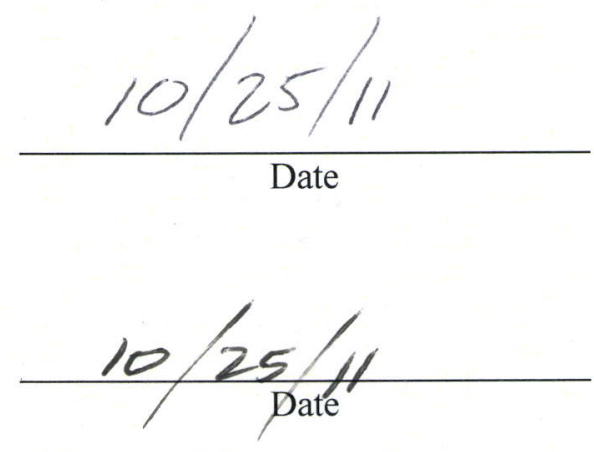



\begin{abstract}
This paper summarizes the evaluation of siting an HTGR plant in a remote area where it could supply steam, electricity, and high temperature gas for the recovery and upgrade of unconventional crude oil from oil sands in Alberta, Canada. This plant was designed to cover an area of $\sim 43,000$ hectares and recover up to $50 \%$ of the bitumen reserves in this area. The application of an HTGR based central energy facility in the Alberta oil sands addresses potential long term issues associated with recovering and upgrading bitumen; principally greenhouse gas emissions and price instability associated with the large quantities of natural gas used currently as the energy supply. The central energy facility design developed in this evaluation addresses these issues by reducing natural gas consumption by $\sim 205$ million standard cubic feet per day $(\sim 4.5$ trillion cubic feet over the life of the plant), and reducing $\mathrm{CO}_{2}$ emissions by $\sim 13$ thousand tons per day ( 285 million tons over the life of the plant).
\end{abstract}




\section{SUMMARY}

This paper summarizes an evaluation of integrating energy supplied by High Temperature Gas-cooled Reactor (HTGR) technology with processes for the recovery and upgrading of bitumen from the Alberta, Canada oil sands. The energy would be supplied from an HTGR central energy facility that would supply steam, electricity, and high temperature gas to multiple oil sands production facilities using the steam assisted gravity drainage process and an upgrading facility. For the purposes of this evaluation a central $3,000 \mathrm{MW}(\mathrm{t})$ HTGR facility is described that can supply the energy needs for recovery of $\sim 150,000$ barrels per day of bitumen using the SAGD process and for upgrading of the bitumen to produce $\sim 145,000$ barrels per day of premium synthetic crude.

The site selected for this evaluation is in the Alberta oil sands. The application of an HTGR based central energy facility in the Alberta oil sands addresses potential long term issues associated with recovering and upgrading bitumen; principally greenhouse gas emissions and price instability associated with the large quantities of natural gas used currently as the energy supply. The central energy facility design developed in this evaluation addresses these issues by:

- Reducing natural gas consumption by $\sim 205$ million standard cubic feet per day ( $\sim 4.5$ trillion cubic feet over the life of the plant)

- Reducing $\mathrm{CO}_{2}$ emissions by $\sim 13$ thousand tons per day ( $\sim 285$ million tons over the life of the plant).

The HTGR facility has a lifetime of at least 60 years. This approach to energy supply, therefore, effectively insulates the oil sands producers over the long term from the potential imposition of carbon costs or issues with natural gas supply and provides a reliable source of energy for at least 60 years at a price that would be affected only by normal inflationary effects on the costs of operating materials and labor.

This plant has the capacity to cover an area of $\sim 43,000$ hectares and recover up to $50 \%$ of the bitumen reserves in this area. The Alberta oil sands cover an area of $\sim 14$ million hectares with an estimated 1.7 trillion barrels of recoverable bitumen. The prospect of constructing several of these central energy facilities would further reduce the consumption of natural gas and $\mathrm{CO}_{2}$ emissions. As an example, a prior NGNP Project study posits that deployment of six central energy supply facilities similar to that described in this report would be sufficient to support $25 \%$ of the expansion of in-situ recovery of bitumen and the upgrading of that bitumen projected for the Alberta oil sands in the 2025 to 2050 time frame. 


\section{ACKNOWLEDGMENT}

The NGNP Project was assisted in completing evaluations and preparing this report by the Petroleum Technology Alliance Canada (PTAC). PTAC's membership includes many of the companies involved in the recovery and upgrading of bitumen from oil sands in Alberta, Canada. The Alternative Energy Solutions (AES) steering committee of PTAC met with INL personnel to discuss the concept of the HTGR Central Energy Facility developed herein, provided data on the relevant processes in use in the oil sands and provided substantive comments on the draft report. As co-authors of this report the PTAC AES is in agreement with INL that the HTGR Central Energy Facility concept has potential applicability as an alternative energy supply for oil sands processes. INL thanks PTAC and, in particular the members of the AES committee, for their assistance in adding "real-life" substance to this report. 


\section{CONTENTS}

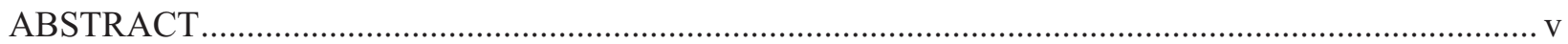

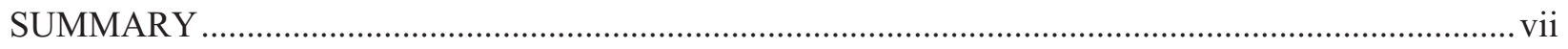

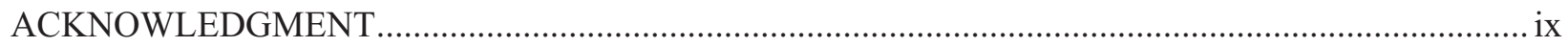

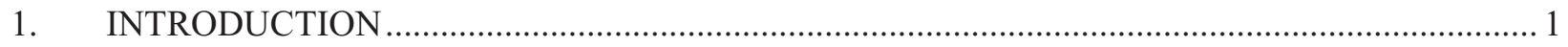

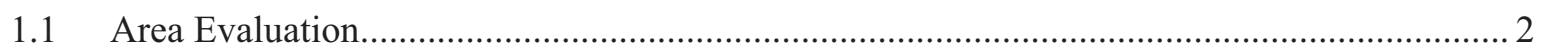

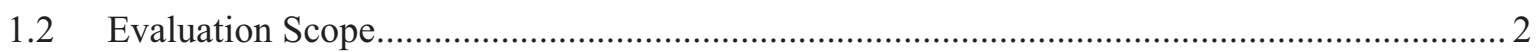

2. APPLICATION OF HTGR TECHNOLOGY TO OIL SANDS OPERATIONS ............................ 3

2.1 Current Oil Sands Operations ....................................................................................... 3

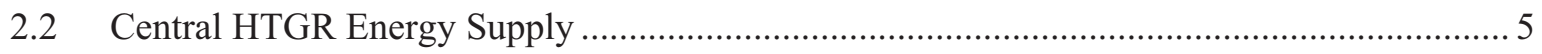

2.2.1 Facility and Energy Transport Concepts............................................................... 5

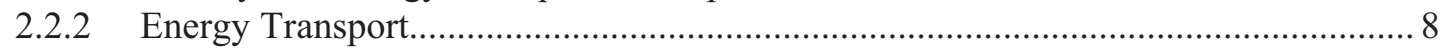

2.3 HTGR Application to Bitumen Recovery and Water Treatment ........................................ 10

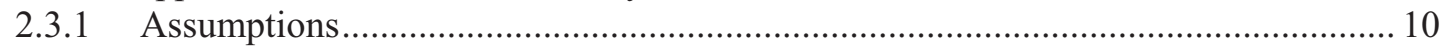

2.3.2 HTGR Central Energy Facility Design Requirements ......................................... 11

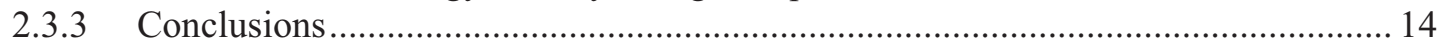

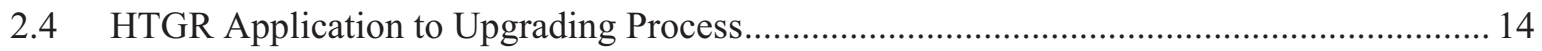

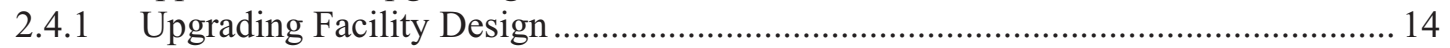

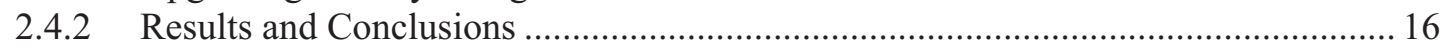

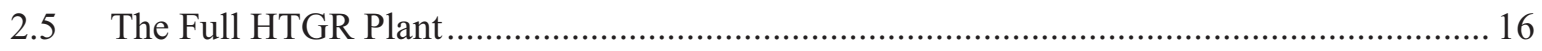

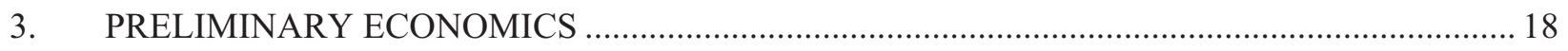

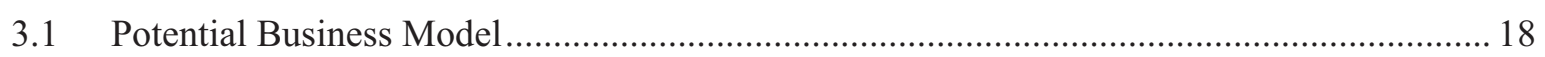

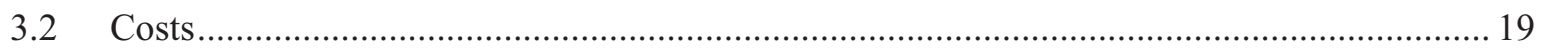

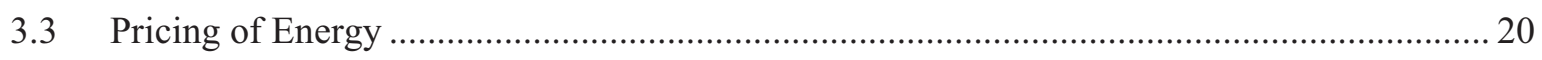

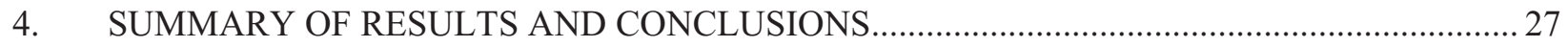

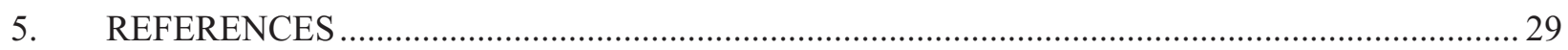

\section{FIGURES}

Figure 1. Typical steam assisted gravity drainage process for bitumen recovery ..................................... 3

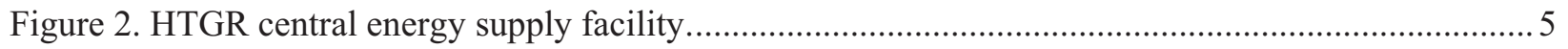

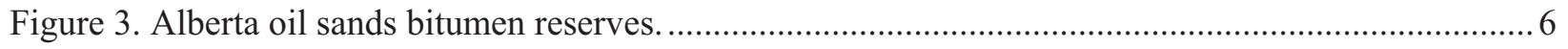

Figure 4. HTGR central energy supply facility distribution of energy to OSPs and upgrading

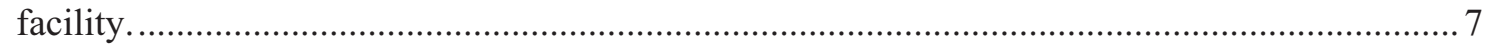

Figure 5. Progressive supply of energy to OSP facilities and well pads................................................ 8

Figure 6. Comparison of conventional (upper) and nuclear integrated (lower) SAGD and water treatment processes. 
Figure 7. Aspen flow sheet for HTGR integrated SAGD and water treatment process.

Figure 8. Comparison of energy supply and requirements for conventional and HTGR integrated SAGD and water treatment processes.

Figure 9. Upgrading diluted bitumen to premium synthetic crude [Source TEV-1147].

Figure 10. Mass and energy balance for conventional and HTGR integrated bitumen upgrading processes [Source: TEV-704, R2].

Figure 11. Comparison of conventional and HTGR integrated mass and energy balance for recovering and upgrading bitumen extracted from oil sands.

Figure 12. Distribution of energy supplied by the HTGR central energy supply plant. .......................... 17

Figure 13. Central energy supply facility business model. .................................................................... 18

Figure 14. Effect of carbon credits on effective HTGR energy price for central energy facility [Source TEV-704].

Figure 15. Effect of variations in key economic parameters on the price of steam................................. 22

Figure 16. Effect of variations in key economic parameters on the price of electricity. ...........................23

Figure 17. Effect of variations in key economic parameters on the price of heat.....................................23

Figure 18. Electricity price, \$/MWhe-probability distribution and statistics.......................................2 24

Figure 19. Steam price, $\$ / 1000$ lb probability distribution and statistics.................................................2 25

Figure 20. Steam price, $\$ / 1000 \mathrm{lb}$ — probability distribution and statistics.............................................26

\section{TABLES}

Table 1. Summary of capital costs estimate for the HTGR central energy facility. ................................ 19

Table 2. Breakdown of cost estimate factors, accounting for the remote oil sands location.....................20

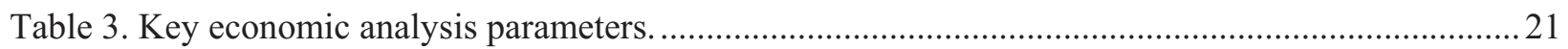




\section{Integration of High Temperature Gas-cooled Reactor Technology with Oil Sands Processes}

\section{INTRODUCTION}

The Next Generation Nuclear Plant (NGNP) Project was initiated at Idaho National Laboratory (INL) by the U.S. Department of Energy (DOE) as part of the Generation IV Nuclear Energy Systems technology roadmap and pursuant to the Energy Policy Act of 2005. ${ }^{1}$ The principal objective of the NGNP Project is to support commercialization of high temperature gas-cooled reactor (HTGR) technology. The HTGR is helium cooled with a graphite core that can operate at reactor outlet temperatures much higher than conventional light water reactors. This allows it to be used as a substitute heat source over the burning of fossil fuels, such as natural gas, in many industrial applications, including the production of electricity - the principal application of light water reactors. The NGNP Project has evaluated applying HTGR produced electricity, steam, and high-temperature gas to a wide range of industrial processes, including the production of hydrogen and oxygen for use in petrochemicals, refining, coal-to-liquid fuels, synthetic feedstocks, chemical and fertilizer plants and steam, electricity and heat for oil shale and oil sands recovery and upgrading processes (the subject of this report). These evaluations investigated both the technical and economic viability and the market potential for these applications. ${ }^{2,3,4}$

As a non- $\mathrm{CO}_{2}$ emitting substitute for the burning of fossil fuels in industrial applications, the HTGR can offset significant quantities of $\mathrm{CO}_{2}$ emissions coming directly from the combustion of fossil fuels in such industrial processes (providing steam, electricity for internal use, supplying high temperature gas) and the emissions associated with electrical power taken from the grid. The use of the HTGR technology as a substitute for the burning of natural gas in many of these applications and for the conversion of coal to synthetic fuels and chemical process feedstock improves the security of the energy supply in the United States by reducing reliance on offshore imports. It reduces the impact of the volatility in energy prices that have been experienced over the last few decades on the economics of industrial processes (wide swings in the prices of oil, natural gas, and coal), and preserves our limited nonrenewable energy resources (e.g., instead of burning natural gas, it is used in more productive and irreplaceable feedstock applications for producing a broad range of chemicals).

Reference 5 provides an overview of the HTGR technology, typical configurations applied in supplying energy to industrial facilities, and a detailed comparison of the technical characteristics of the two reactor concepts used to implement this technology - the prismatic block and pebble bed reactor concepts.

The NGNP Project has been supporting commercializing of HTGR technology by defining tasks to assess the feasibility of siting the HTGR to support different industrial applications under different site conditions (e.g., brownfield closely co-located with petrochemical, refining, or other industry with high and varied energy usage; brown or greenfield on an existing nuclear site in close proximity to one or more potential energy off-takers; brown-or greenfield in a remote location; and greenfield for electricity generation and distribution only). The NGNP Project also evaluated siting an HTGR within or close by an existing petrochemical facility and at an operating nuclear plant site in a cogeneration application where the HTGR plant will be supplying steam and electricity to one or more of the nearby industrial plants.

This paper summarizes the evaluation of siting an HTGR plant in a remote area where it would supply steam, electricity, and high temperature gas for the recovery and upgrade of unconventional crude oil from oil sands in Alberta, Canada. 


\subsection{Area Evaluation}

The oil sands of Alberta, Canada were selected for this evaluation. This is a fertile and active area for recovering and upgrading bitumen, with significant quantities being piped to refineries in Canada and the United States. Many of the active sites and land leases land for recovery are owned and operated by U.S. petroleum companies. Data pertaining to energy consumption and other factors required to complete the evaluation of the HTGR application is readily available in the public domain. The Alberta Oil Sands Producers (OSP) are also interested in identifying alternative energy sources for their operations. The Alternative Energy Solutions subcommittee of Petroleum Technology Alliance Canada, which represents many of the companies involved in Alberta oil sands, provided substantive information and reviews in support of this report.

The two methods currently being applied in recovering ${ }^{\mathrm{a}}$ bitumen from oil sands in Alberta are mining and in-situ recovery. The latter uses the steam assisted gravity drainage (SAGD) process evaluated in this report for potential application of energy supplied by HTGR technology. Natural gas is the primary fuel currently used to supply the energy for oil sands operations. Concerns with the environmental impact of burning this fuel and the effect of fluctuations in natural gas prices have prompted the OSPs to investigate alternative energy sources. An HTGR is one alternative with the potential to provide the necessary energy without any greenhouse gas emissions and at a long term stable price. It is particularly suited for this application because its high operating temperature can supply energy efficiently at the conditions required by the SAGD and bitumen upgrading processes. Reference 6 compares the HTGR technology with other higher temperature reactor concepts for use in supplying energy for oil sands operations.

\subsection{Evaluation Scope}

This evaluation assesses the technical and economic viability of using HTGR technology as the energy supply for recovering bitumen from oil sands and upgrading the bitumen to synthetic crude oil. The synthetic crude oil is then shipped to refineries for further refining into petroleum based products such as gasoline and diesel fuels. This evaluation: identifies and characterizes the energy used in current process operations, identifies where the HTGR energy could be used in these processes, develops the HTGR functional and performance requirements necessary to supply the energy in the required forms and quantities, develops process and HTGR plant designs for each process, and completes preliminary economic analyses to establish the price of energy from the HTGR plant. The processes evaluated include:

- Bitumen recovery using SAGD, which includes steam generation, recovered water treatment (water recovered from the SAGD wells along with the Bitumen), and bitumen dilution with naphtha

- Bitumen upgrading to premium synthetic crude oil

- Electricity generation for specific and general oil sands operations.

a In this paper, recovery of bitumen includes extraction of bitumen and water using SAGD, separation, and treatment of the water for reuse and dilution of the bitumen for transport to an upgrading facility or a refinery. As noted, naphtha is assumed to be the diluent. 


\section{APPLICATION OF HTGR TECHNOLOGY TO OIL SANDS OPERATIONS}

\subsection{Current Oil Sands Operations}

The oil sands contain large quantities of bitumen, which is a complex mixture of solid or semi-solid hydrocarbons, typically having a density of $10^{\circ}$ API or less. Bitumen can also contain impurities that must be removed either prior to or as part of refining. These impurities include sulfur $(2-7 \%)$, nitrogen $(0.2-$ $0.7 \%$ ), oxygen (up to $1.2 \%$ ), nickel (up to $200 \mathrm{ppm}$ ), and vanadium (up to $1,100 \mathrm{ppm}$ ). The SAGD process is used to extract the bitumen from buried deposits that are not practically recoverable using the mining process. A schematic diagram of a conventional SAGD operation is shown in Figure 1. The operation consists of a SAGD well pair; the top horizontal well is used to supply steam and the lower horizontal well is used to collect the heavy oil product. The wells run parallel to each other. The top and bottom wells are located 150 to 350 meters below the surface, are separated by approximately five meters, and are up to 1,000 meters long. The injected steam travels along the upper perforated-well bore and heats the oil sand deposits in the vicinity of the upper well. After the deposit is heated, the bitumen becomes fluid and drains to the lower perforated-well where either the steam pressure is sufficient to raise it to the surface, or it is pumped out and collected along with water condensed from the injected steam. The bitumen/water mixture is then sent through a water/oil separation system. More than $90 \%$ of the water can be recovered and recycled back to the steam generator after it is sufficiently treated. The recovered bitumen is then mixed with a diluent, assumed to be naphtha, to provide fluidity for conventional pipeline transport to an upgrading facility.

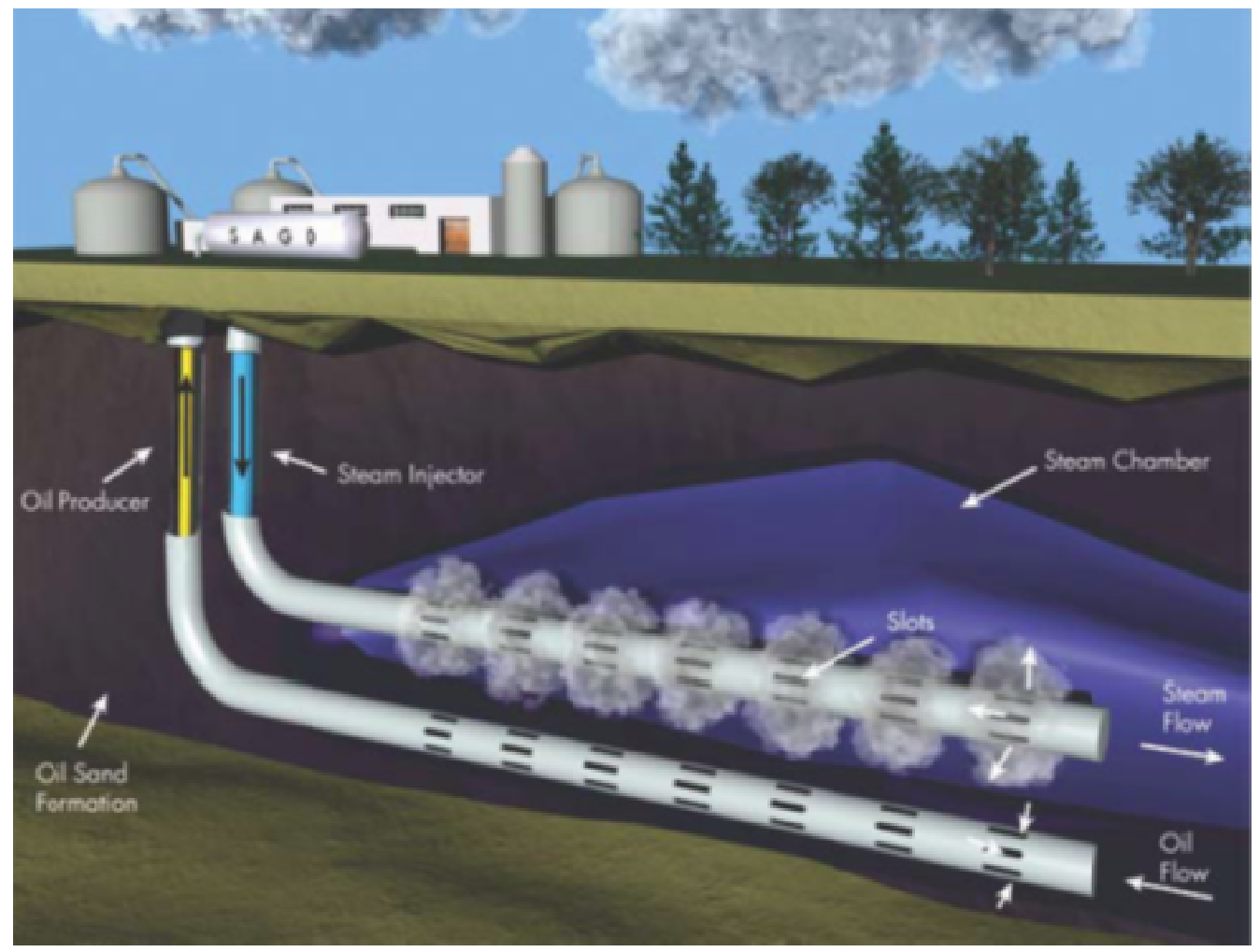

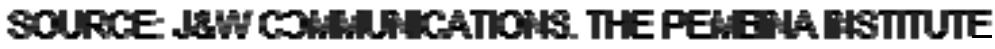

Figure 1. Typical steam assisted gravity drainage process for bitumen recovery. 
In a typical application several well pairs will be sited in a well pad. Currently, steam generated at the OSP facilities is supplied to each well pad from a natural gas fired boiler that can be up to $15 \mathrm{~km}$ from the well pad site. The bitumen and water recovered from all of the well pairs within a well pad are pumped back to the boiler site for separation of the water from the bitumen and dilution of the bitumen with naphtha or other diluent, (e.g., synthetic crude). The diluted bitumen (referred to as DilBit) is then pumped to a refinery or upgrading facility.

Many potential process configurations are possible for upgrading bitumen. The optimal upgrading strategy used by a bitumen producer depends on many variables, including unused refining capacity at existing refineries and the capability of existing refineries to handle the heavy (residue) fraction of the bitumen. The strategies most commonly considered for upgrading bitumen are as follows:

1. Decrease bitumen viscosity by dilution to enable transport via pipeline to an existing refinery. As previously noted, this is done at the OSP facility by providing steam to the well pads and treatment of the recovered bitumen and water mixture. This low-cost option is attractive when an existing refinery has additional capacity along with the capability to process the heavy fraction of bitumen. Natural gas condensates are typically used as the diluents, resulting in a blend known as DilBit. The diluent is typically separated from the bitumen at the refinery and piped back to the bitumen recovery for reuse. It is also common to use syncrude as the diluent (SynBit) or a combination of natural gas condensate and syncrude (SynDilBit). The choice of diluent is highly dependent on the capability and capacity of the refinery to process the heavy fraction of bitumen.

2. Reduce bitumen viscosity and control solids and water using a minimal upgrading approach. Significant research is underway on simple, small-scale processes. ${ }^{7}$ This option is primarily attractive when an existing refinery has additional capacity and capability to process the heavy fraction of bitumen. Unlike the dilution approach, this option does not require the diluent to be returned to the extraction site.

3. Reduce sulfur and maximize distillable oil using a full upgrading approach. This option is attractive when existing refinery capacity does not exist, or when an existing refinery cannot be easily modified to accommodate the heavy fraction of bitumen. Numerous full upgrading scenarios have been implemented and/or proposed. One approach is to produce a crude product that contains only a small amount of sulfur and heavy residue and very closely resembles petroleum-based crudes. A second approach is to produce a crude product that has been sweetened (sulfur removed to low levels) and contains no heavy residue. Such crude typically trades at a premium over petroleum-based crudes and is referred to as premium syncrude.

The full upgrading approach (Strategy 3) is more amenable to integration with HTGR technology because it requires electricity, heat, and hydrogen, all of which are readily available products from the HTGR, thereby achieving the most economical application of HTGR energy. Upgrading to premium synthetic crude also adds the most value to the bitumen for export. Hence, the remainder of this paper assumes premium synthetic crude (syncrude) production from bitumen via the full upgrading approach.

Finally, all of these processes and general operations in the oils sands, including domestic demand, require electricity. The high temperature capability of the HTGR technology results in generation of electricity at efficiencies comparable to traditional fossil based electricity generation. The HTGR can be used to generate electricity using traditional subcritical and supercritical Rankine cycle steam turbine generators (net efficiencies up to 45\%), Brayton gas turbine combined cycles (net efficiencies $>45 \%$ ) and direct Brayton cycle gas turbines (net efficiencies $\sim 50 \%$ ). The subcritical Rankine cycle is assumed for electricity generation for the purposes of this paper. 


\subsection{Central HTGR Energy Supply}

\subsubsection{Facility and Energy Transport Concepts}

Figure 2 depicts a notional layout of a centralized energy supply facility utilizing the HTGR as the source for oil sands energy needs. The areas over which this facility could supply these energy needs depends on the specific location and the reserves of bitumen available in that location. Figure 3 is a map of the Alberta oil sands region showing the distribution of bitumen reserves known at the time of this writing. These reserves are those expected to be available in the mid- to late-2020s when the HTGR technology is expected to be commercially available. The total oil sands area covers $\sim 14$ million hectares containing $\sim 1.7$ trillion barrels of bitumen. The recoverable volume of bitumen is quoted as 170 billion bbl (barrels). 30 billion bbl of that is minable; leaving 140 billion bbl recoverable using SAGD methods. If more economic methods are developed for SAGD recovery this value could increase. In any event, there are considerable bitumen reserves to which the SAGD process, supported by an HTGR based central energy supply facility, could be applied.

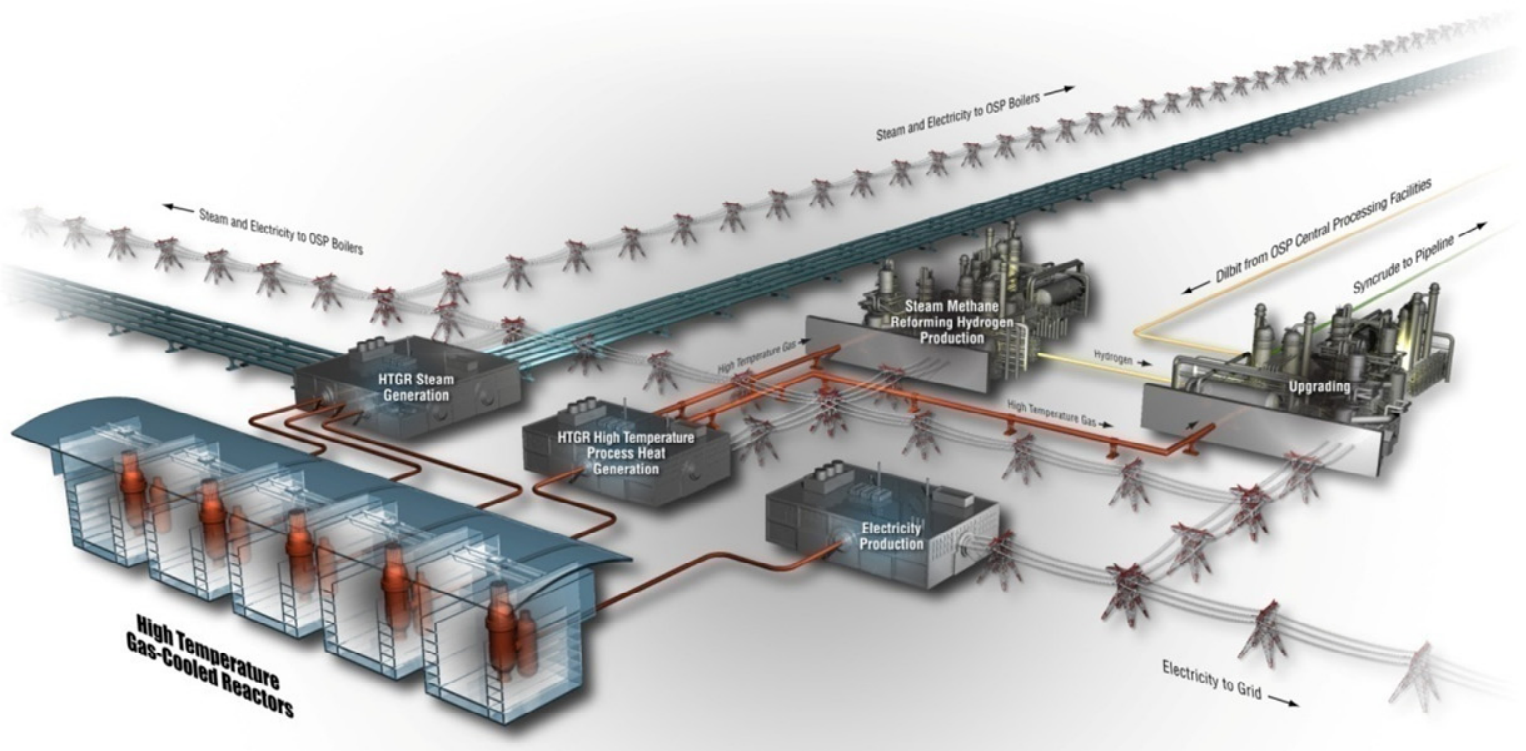

Figure 2. HTGR central energy supply facility. 

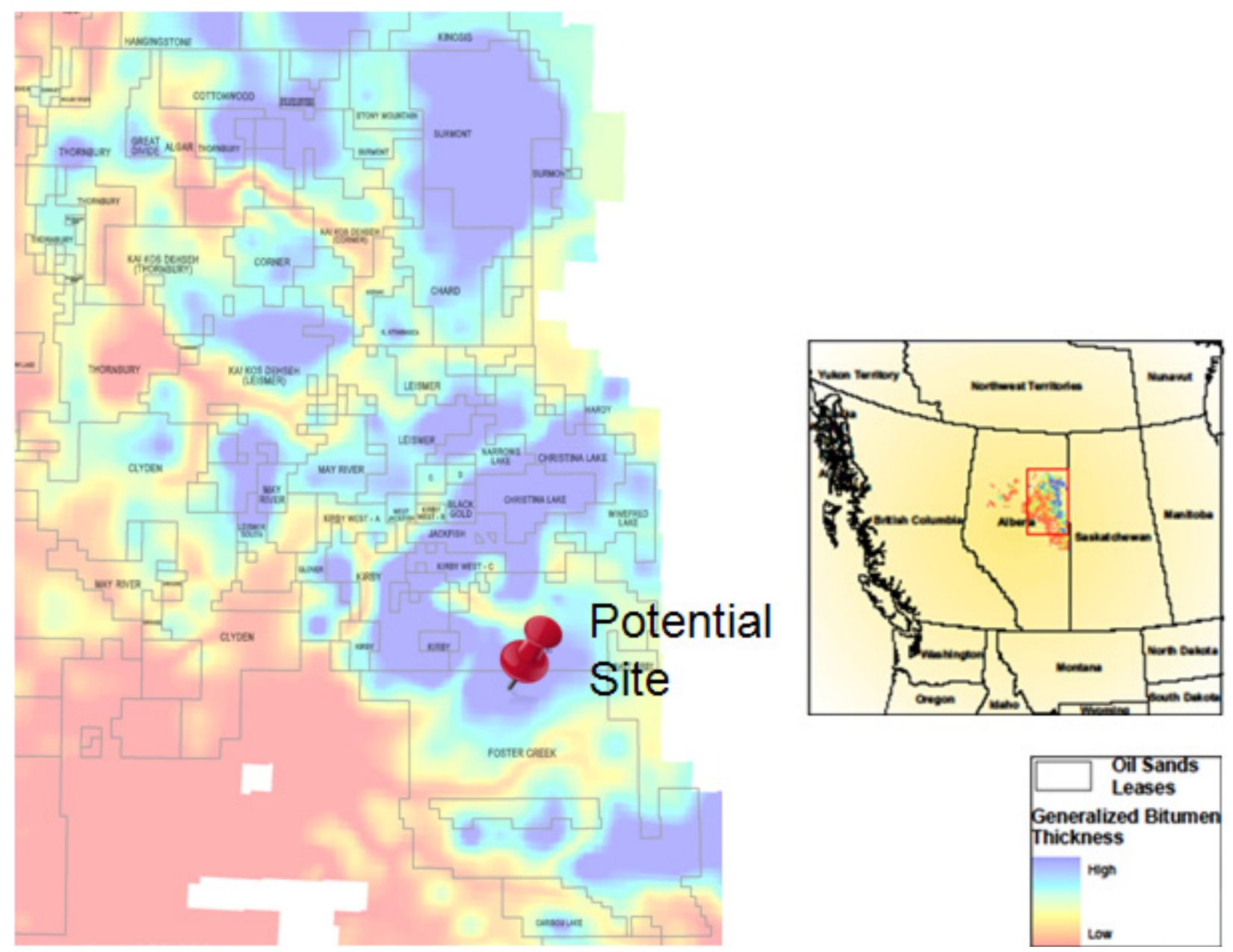

Figure 3. Alberta oil sands bitumen reserves.

For the purposes of this paper it is assumed that the HTGR based central energy facility would be located in the region identified with the push pin. Over the 60-year life of the HTGR facility, bitumen resources could be recovered at current rates from an area of $\sim 43,000$ hectares. This facility will supply steam and electricity to multiple oil sands producers for the: generation of steam for extraction of bitumen from multiple well pads, separation of the recovered water from the bitumen, dilution of the bitumen for transport to the central upgrading facility, and treatment of the recovered water for use in the facility steam generator. Depending on the configuration of the area to be covered, this may require transport of HTGR energy to remote oil sands producer facilities up to $25 \mathrm{~km}$ from the central facility. This facility will also supply the necessary energy to a centrally located facility that will upgrade the bitumen recovered from the serviced well pads to premium synthetic crude oil. This upgrading facility is assumed to be closely located with the central energy supply facility. Figure 4 depicts this arrangement. 


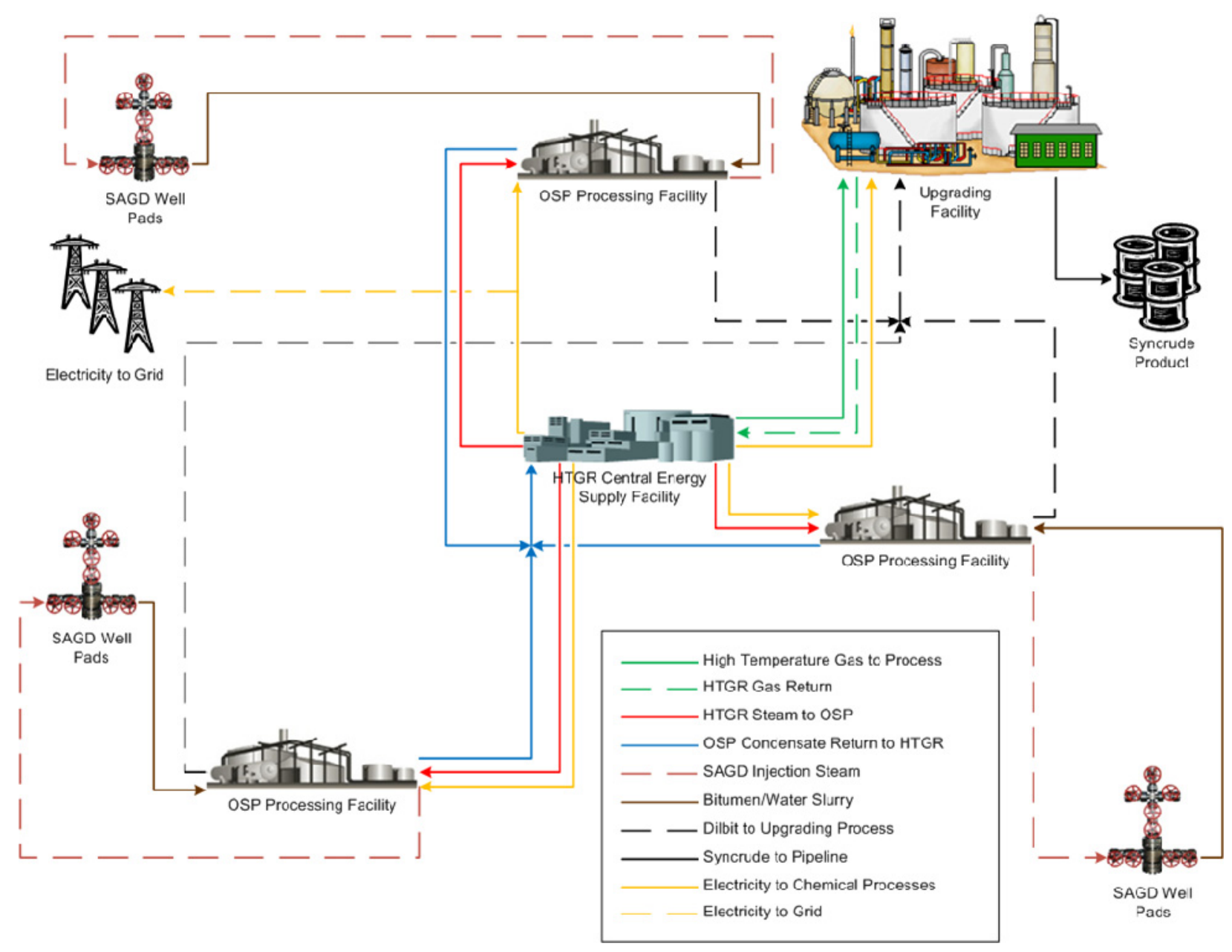

Figure 4. HTGR central energy supply facility distribution of energy to OSPs and upgrading facility.

As shown in Figure 4, the HTGR plant will be sized to supply several OSP facilities and the upgrader. It is assumed that the OSPs will extract bitumen from the area shown in Figure 3 progressively over the lifetime of the HTGR plant. Figure 5 shows this progression. Note that only two OSP facilities are required to cover the area selected. The HTGR plant design developed for this application supplies energy to these two OSP facilities, the upgrading facility and the oil sands electrical grid.

The area shown is estimated to have sufficient recoverable bitumen to support the 60 year lifetime of the HTGR plant and covers an area of $\sim 43,000$ hectares. 

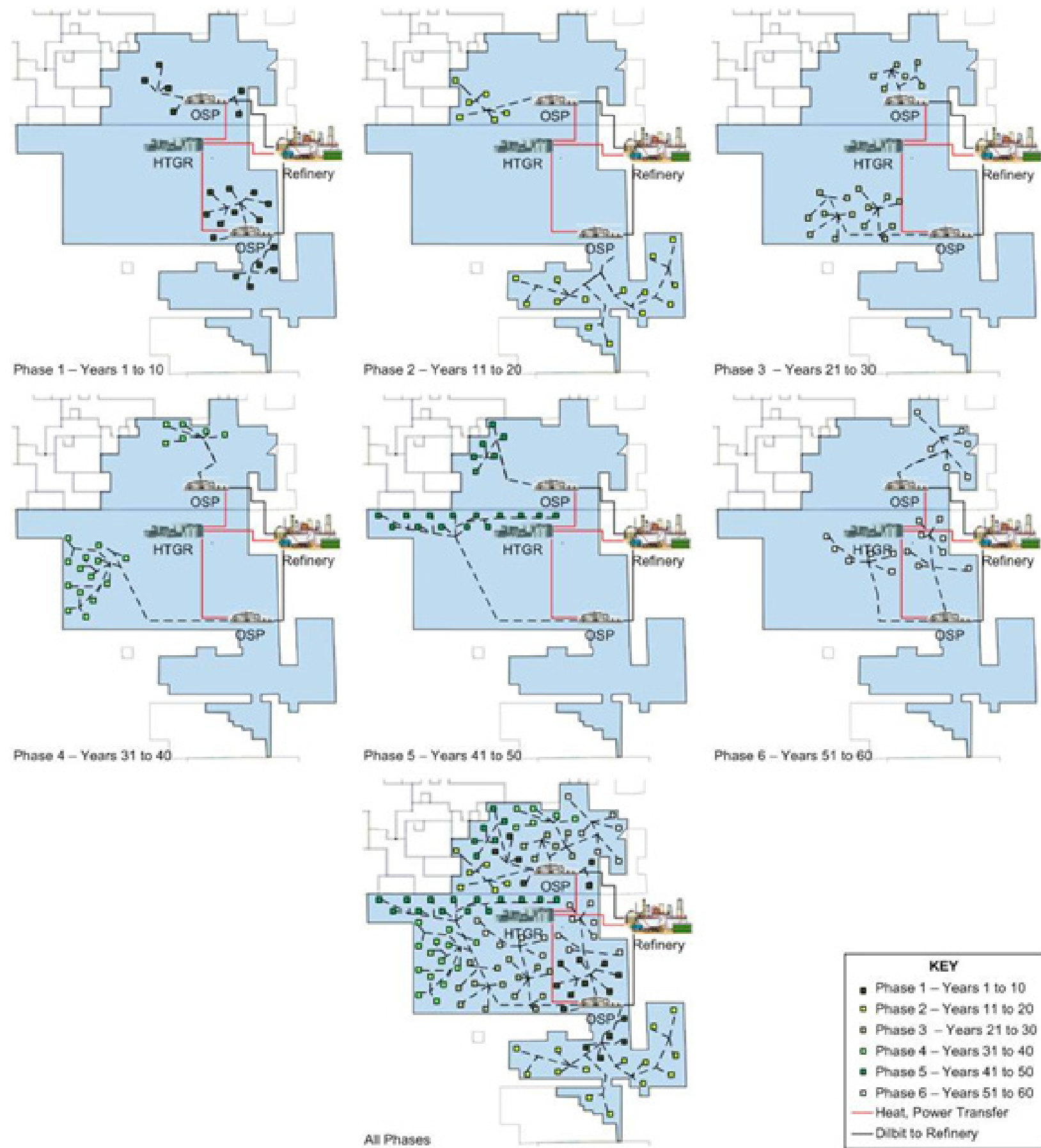

Phase 6 - Years 51 to 60

Figure 5. Progressive supply of energy to OSP facilities and well pads.

\subsubsection{Energy Transport}

The forms of energy transported from the central facility to the processes will be steam, electricity and heat. The transport of electricity will be via dedicated electrical distribution lines to the OSP facilities and to the oil sands electrical distribution system for general use. High temperature piping will be used to transport heat to the central upgrading facility, which is assumed to be closely collocated with the HTGR plant. These are conventional approaches to energy transport. A separate study was conducted, however, 
to establish the most efficient approach for transport of energy to the oil sands producer facilities over the span of up to $25 \mathrm{~km}$. This energy will be used instead of natural gas firing for the generation of steam at each OSP facility.

In this study it was assumed that energy will be transferred to the OSP facilities in a fluid that can be used to generate steam in new reboilers at the OSP facilities at the appropriate conditions for bitumen recovery using SAGD and to support treatment of the recovered water for reuse in the OSP reboilers. It is further assumed that the energy transport will be a closed cycle with the transport fluid returned to the HTGR plant. Several transport fluids were evaluated for this purpose in INL TEV-1351 ${ }^{8}$ :

- Water/Steam

- Helium

- Carbon dioxide

- DOWTHERM A

- Molten Salt: FLiNaK.

The conclusion of this study was that steam is the preferred transport fluid. This conclusion is based on the following characteristics of steam compared with the alternative fluids:

- It has high heat capacity resulting in acceptable pipeline configurations to each OSP; particularly when compared with helium and carbon dioxide.

- The total mass of fluid required is close to the lowest required of the acceptable alternatives; FLiNak has the highest mass.

- The cost of the fluid is the lowest of the alternatives; FLiNaK and DOWTHERM A are among the highest cost.

- It is chemically benign; particularly when compared with FLiNaK.

- There is a large body of experience in transport of steam over considerable distances (e.g., in refining and petrochemical plants).

In addition:

- The organic fluids, (e.g. DOWTHERM A) do not have the capability of operating at the required temperatures for sustained periods. These fluids degenerate when operated at high temperatures, which would require frequent replacement at high cost.

- The gases do not have sufficient heat capacity to practically transport the energy over the required distances; multiple large and expensive pipelines would be required.

- Molten salt or liquid metals are effective heat transport fluids but are judged to be impractical for this application. They need to be kept at high temperatures such as $>250^{\circ} \mathrm{C}$ to prevent freezing, which would require extensive and expensive heat tracing along the pipelines. These materials are expensive and heavy requiring significant structure to support the pipeline and they are corrosive requiring special handling.

The evaluations in this paper, therefore, are based on using steam for transport of energy to the OSP facilities. 


\subsection{HTGR Application to Bitumen Recovery and Water Treatment}

Evaluation of the application of the HTGR technology for bitumen extraction from oils sands using the SAGD process and treatment of the water recovered with the bitumen is covered in detail in TEV-704, R2. ${ }^{9}$ The following summarizes the results of that evaluation.

\subsubsection{Assumptions}

The following assumptions were made in establishing the energy requirements for SAGD processing $^{\mathrm{b}, 10}$ :

- There are 10 well pairs per well pad

- Well pads have a life of 10 years

- Each well pad will extract 7,500 bpd (barrels per day) of bitumen (750 bpd per well pair)

- The HTGR facility will have sufficient capacity to supply 20 well pads simultaneously producing $\sim 150,000$ bpd of bitumen (over the 60 year lifetime of the HTGR plant, 120 well pads with 1,200 well pairs will be supplied)

- The bitumen will be blended with naphtha for transport to the upgrading facility; the diluted fluid (known as DilBit) is $70 \%$ by volume bitumen $(\sim 210,000$ bpd of DilBit is produced)

- The steam to oil ratio by volume is 2.5 ; this was identified by oil sands producers as an acceptable assumption as it is mid-range in current oil sands experience; SOR $=2.2-3.0(94 \%$ of the water is recovered)

- Steam conditions:

- Central Energy Supply facility $16 \mathrm{MPa}, 540^{\circ} \mathrm{C}$, superheated

- OSP supply: $\quad 10 \mathrm{MPa}, 310^{\circ} \mathrm{C}$, saturated

- Well pair Injection: $\quad 5 \mathrm{MPa}, 264^{\circ} \mathrm{C}$, saturated

- The OSP facilities are located up to $25 \mathrm{~km}$ from the central energy supply facility. This distance was selected for analysis purposes. There is sufficient temperature and capacity in the HTGR technology to extend this distance further. However, it may not be economic to transport steam farther than $25 \mathrm{~km}$. It is judged that the $25 \mathrm{~km}$ will more than cover the area that can be supplied by a central energy plant. For the service area shown in Figure 5, for example, the distances to the OSP facilities are much shorter; less than $10 \mathrm{~km}$, and a very large area is covered. The principal HTGR plant design factors affected by this distance are the required rating of the HTGR steam supply, the number and cost of steam piping, and the length of the electrical transmission lines required to supply the steam and electricity to the OSP facility. These all have influence on the economics of the application.

- The well pairs are located up to $25 \mathrm{~km}$ from the OSP facilities. This is an upper bound for analysis purposes; the maximum distance from current OSP facilities to the well pads is understood to be $\sim 15 \mathrm{~km}$.

- Total electricity requirements at the two OSP facilities: $85 \mathrm{MW}(\mathrm{e})$

- Potential total bitumen recovery:

- $\quad 50 \%$ of the bitumen in a deposit can be recovered

- $\quad 7.5$ barrels of bitumen can be recovered per square meter

b. These assumptions were validated in discussions with oil sand producers 
- 75,000 barrels per hectare

- 43,000 hectares recoverable over the 60 year lifetime of the HTGR.

\subsubsection{HTGR Central Energy Facility Design Requirements}

These assumptions were applied in establishing the energy requirements for recovery of the bitumen using the SAGD process and treatment of the water recovered with the bitumen and, therefrom, the rating, nature of the energy forms and configuration of the HTGR central energy supply.

Figure 6 compares the current conventional energy supply for bitumen recovery and water treatment with that consistent with energy supplied from the HTGR central energy supply. As shown there is little difference in the processes at the OSP facility for the two approaches. The principal difference is that a steam-to-steam reboiler replaces the natural gas fired boiler for steam generation. The steam conditions generated at the OSP facilities are the same as currently supplied (unless there is advantage in changing them) and the operations at the well pads and for water treatment are unchanged.

Figure 7 is an Aspen model flow sheet showing nominal conditions for supplying OSP facilities that supply 20 well pads. The OSP facilities are shown $25 \mathrm{~km}$ from the HTGR central energy facility and the well pads are $25 \mathrm{~km}$ from the OSP facilities. In the actual application the OSP facilities and well pads may be more closely located. These distances were selected as a potential upper bound for the purposes of analysis. Note that these distances can be longer by increasing the HTGR energy supply temperature and the OSP facility supply pressure; but this would increase the price of energy from that calculated herein. Thermal hydraulic conditions are shown at major locations in the flow sheet for bitumen recovery, recovery of retained heat in the HTGR steam for water treatment, pumping of the HTGR steam condensate back to the central facility, diluting the bitumen, and pumping the diluted bitumen to the upgrading facility.

Figure 8 compares the energy supply and products of the conventional with the HTGR processes. As shown, production of $\sim 150,000 \mathrm{bpd}$ of bitumen requires $\sim 2,400 \mathrm{MW}(\mathrm{t})$ of HTGR energy for the production of steam and electricity. As described in Reference 5, HTGR is a modular technology with module ratings from 200 to $625 \mathrm{MW}(\mathrm{t})$. As shown in Figure 8, the assumption is that the HTGR plant would be supplying the energy to support the SAGD processes with 4 to $600 \mathrm{MW}(\mathrm{t})$ modules. Note that the HTGR plant would be oversized and include backup facilities to ensure that sufficient steam and electricity can be supplied $100 \%$ of the time. These backup facilities could be existing natural gas fired and would be used only if needed during refueling or maintenance of the HTGR modules. 

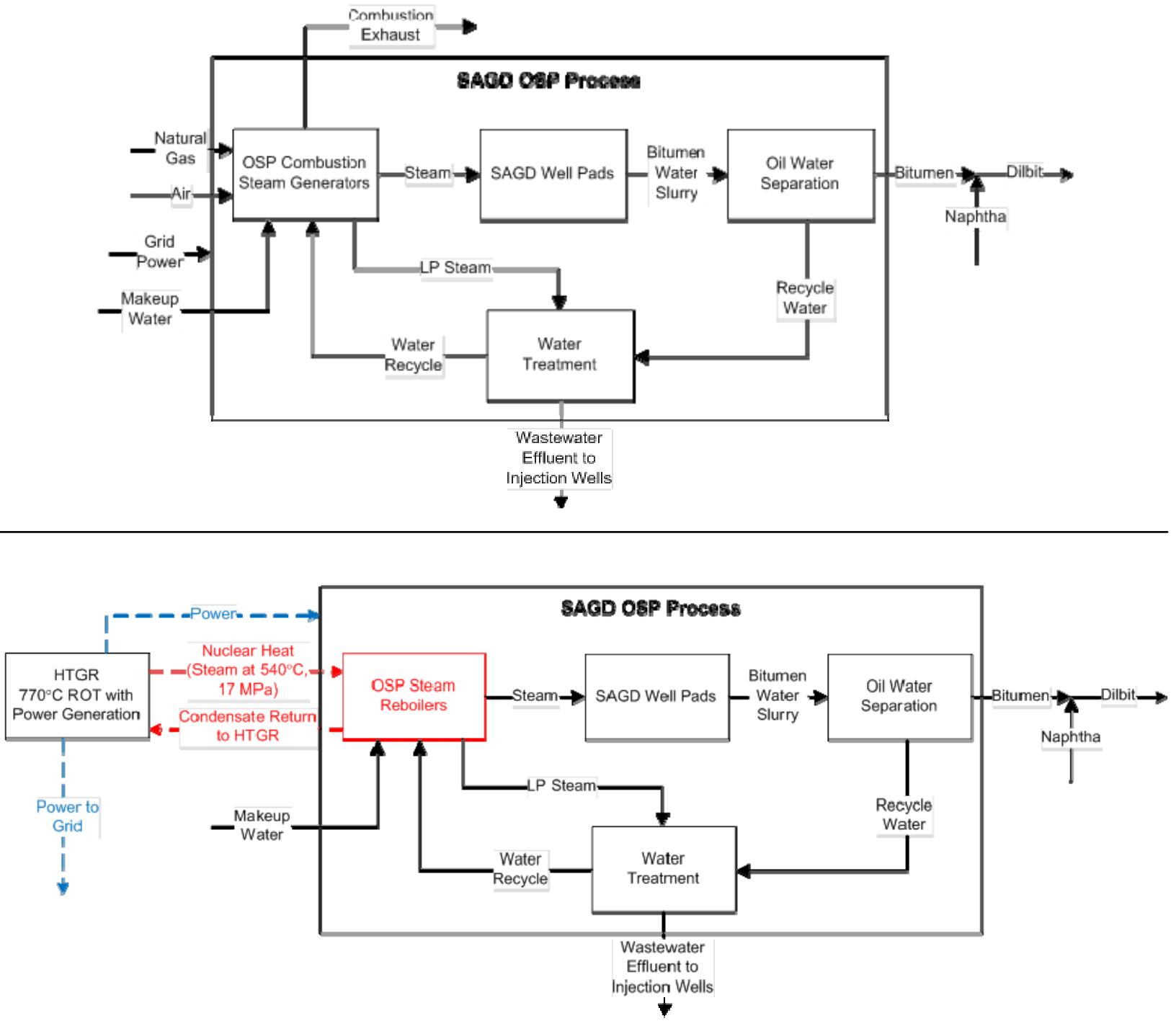

Figure 6. Comparison of conventional (upper) and nuclear integrated (lower) SAGD and water treatment processes. 


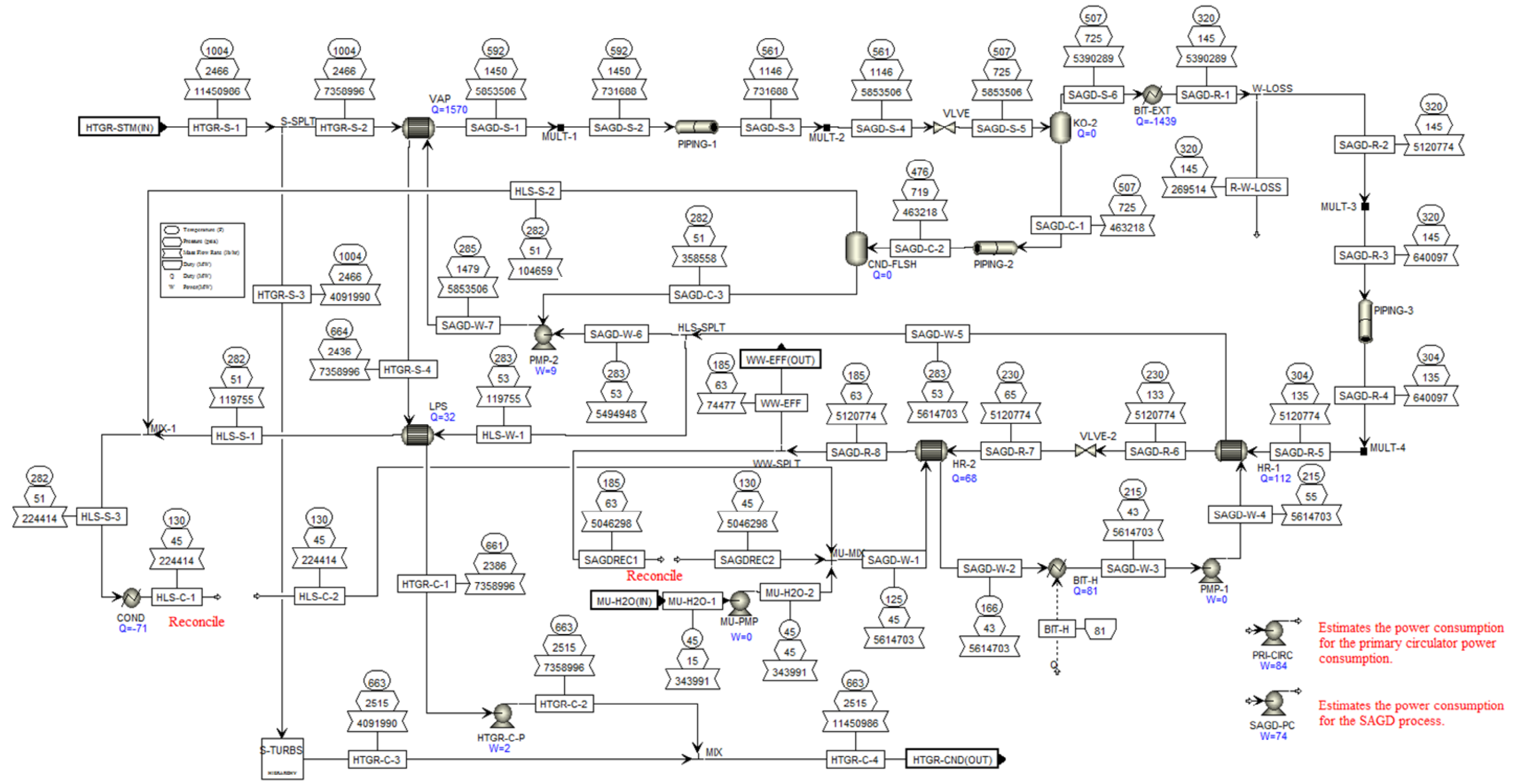

Figure 7. Aspen flow sheet for HTGR integrated SAGD and water treatment process. 

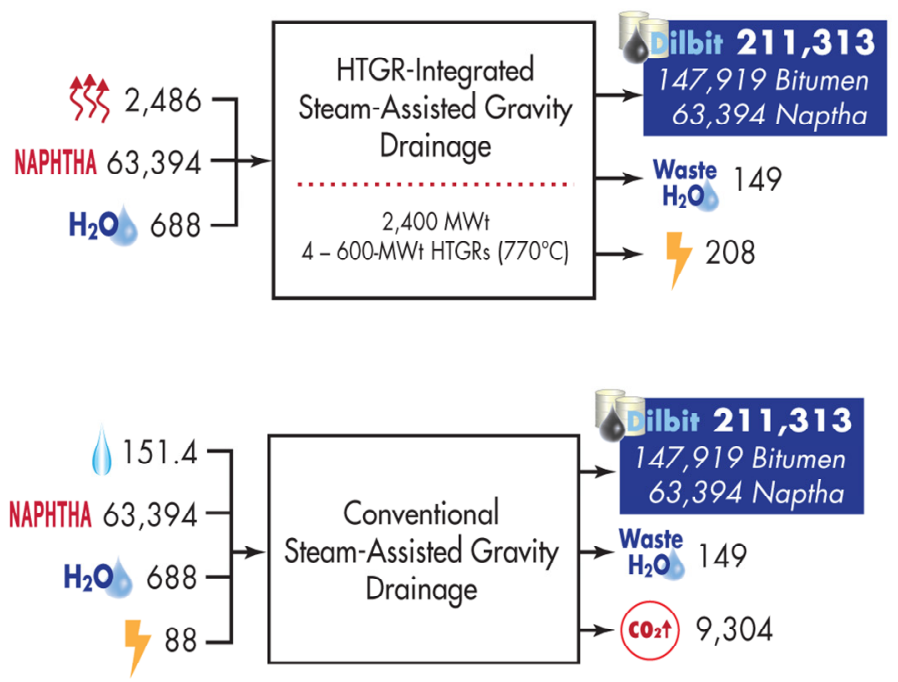

\author{
Q7ilibit Dilbit (barrels/day of \\ bitumen and naphtha)

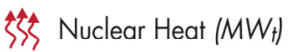 \\ () Natural Gas (MMSCFD) \\ $\mathrm{H}_{2} \mathrm{O}$ / Waste Water / Wastewater \\ (gallons/minute) \\ (Co 14 Carbon Dioxide Emitted (tons/day) \\ NАРНTHA Naphtha (barrels/day) \\ 7 Electricity $\left(M W_{e}\right)$
}

Figure 8. Comparison of energy supply and requirements for conventional and HTGR integrated SAGD and water treatment processes.

\subsubsection{Conclusions}

Use of HTGR energy to support bitumen recovery and water treatment has been shown to be technically viable. The substitution of the HTGR energy supply for the traditional firing of natural gas would result in reduced natural gas consumption of $151.4 \mathrm{mscfd}$ (million standard cubic feet per day) with reduced carbon dioxide emissions of 9,304 tons per day. Accordingly, the HTGR integrated source of energy is effective in preserving the resources of natural gas and in reducing greenhouse gas emissions attendant to the recovery of bitumen from oil sands and treatment of the water recovered with the bitumen.

\subsection{HTGR Application to Upgrading Process}

Integration of the HTGR technology to supply energy for bitumen upgrading is covered in detail in INL TEV-1147. ${ }^{11}$ The following excerpts from this technical evaluation (TEV) summarize the results of that evaluation.

\subsubsection{Upgrading Facility Design}

The full upgrading approach producing premium synthetic crude is amenable to integration with HTGR technology and adds the most value to the bitumen recovered from the oil sands. In this application, the HTGR supplies electricity, heat, and hydrogen, all of which are readily available products from the HTGR technology. The process selected for evaluation is shown in Figure 9. This process separates water, sand, and diluent from the bitumen in a pretreatment step. The bitumen is then fractionated by distillation into various petroleum cuts and a heavy vacuum residuum. The vacuum residuum is then sent to the primary upgrading hydroconversion unit where the vacuum residuum is catalytically reacted under high pressure and temperature in the presence of hydrogen. Longer hydrocarbon chains are broken into shorter chains. The relatively small fraction of vacuum residuum that does not react sufficiently in the hydroconversion unit is sent to a coking unit. The oil products from primary upgrading are subsequently mixed with similar oil products from the initial bitumen fractionation and the coker. These oils streams are then hydrotreated to remove sulfur, vanadium, nickel, nitrogen, and oxygen. Hydrotreating also saturates olefins produced in the coker. 


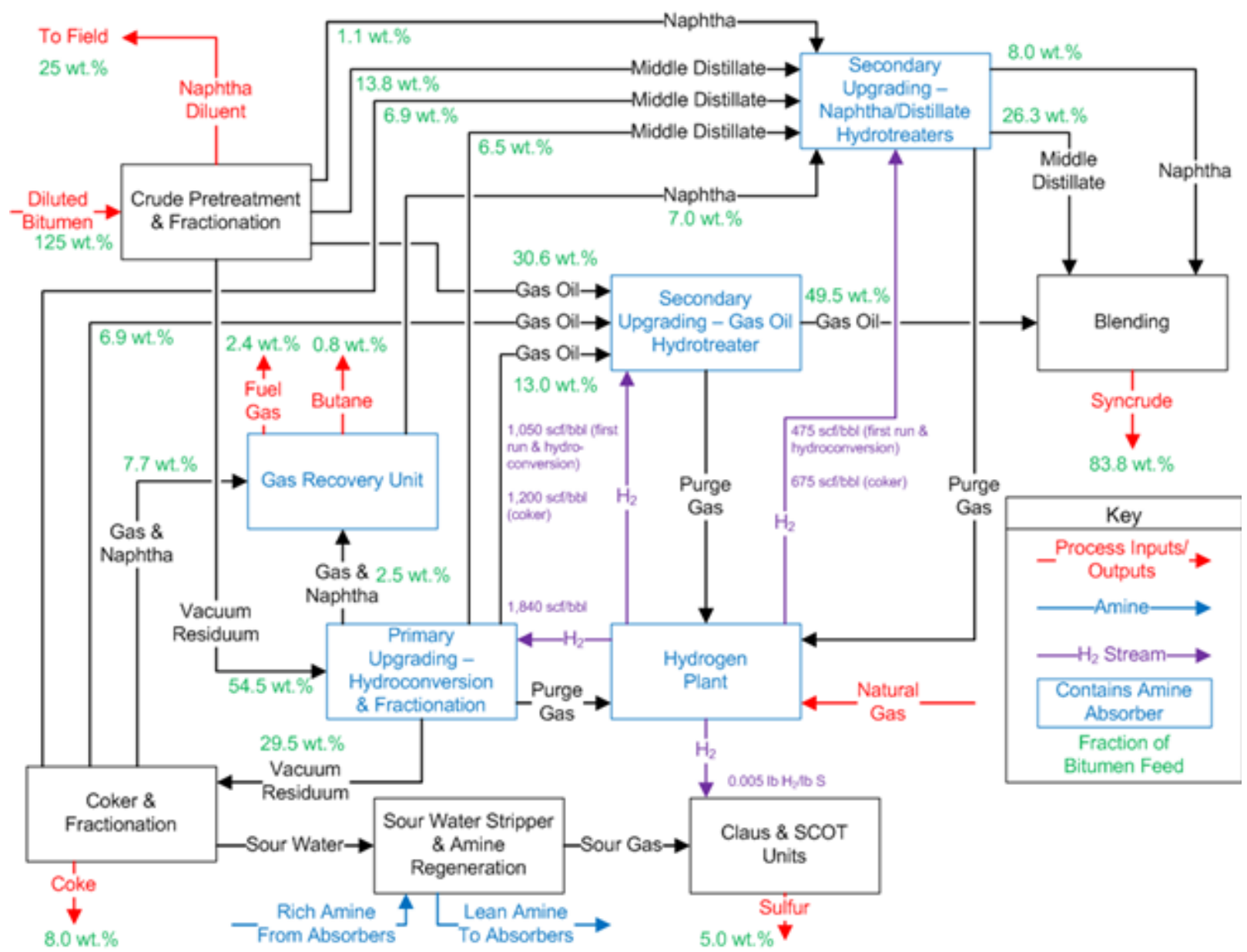

Figure 9. Upgrading diluted bitumen to premium synthetic crude [Source TEV-1147].

Additional unit operations are required to produce hydrogen for the plant and manage the sulfur removed in the primary and secondary upgrading units. The syncrude product is very high quality. It contains no residuum material and is very low in sulfur, metals, oxygen, nitrogen, and olefins. This process is well described in public documentation and was selected as the baseline to integrate with an HTGR, and is used as the basis for all calculations performed in this report.

The results of developing a high level material balance for this process are shown on Figure 11. Material flows are shown as a percentage of the original bitumen feed to the upgrader. Hydrogen requirements for the various hydroconversion and hydrotreating unit operations are also shown. Since these values do not change as a result of HTGR integration, they apply equally to both the conventional and HTGR-integrated configurations. Premium synthetic crude produced from this process is predicted to equal $83.8 \mathrm{wt} \%$ of the bitumen feed.

It was assumed that the HTGR would be coupled with steam methane reforming to supply hydrogen to the upgrader. It was also assumed that light hydrocarbon gas produced in the upgrading process would be burned to supply heat for the upgrader (with the exception of butane, which was assumed to be a salable product). The HTGR was used to supply process heat beyond what could be supplied by combustion of the light hydrocarbon gas. No attempt was made in this evaluation to match specific heat sources (light gas combustion vs. HTGR heat) with specific locations requiring process heat - the assumption was made that enough light gas would be available to meet all heating needs that require a temperature greater than $900^{\circ} \mathrm{C}$. 


\subsubsection{Results and Conclusions}

A summary of material and energy flows for the reference and HTGR-integrated steam methane reforming configurations are presented in Figure 10. The material balances were performed on a mass basis; however, many of these results have been converted to a volumetric basis in Figure 10 in order to conform to conventions standard in the petroleum industry. The following summarizes the salient results:

- Natural gas consumption is reduced by $43 \%$ from 124.9 to $71.4 \mathrm{mscfd}$.

- $\mathrm{CO}_{2}$ emissions are reduced by $33 \%$ from 8,793 to 5,890 tons per day.

- $\quad$ The HTGR energy requirement is $585 \mathrm{MW}(\mathrm{t})$.

The use of HTGR energy to upgrade bitumen to premium synthetic crude has been shown to be technically viable. Applying HTGR technology as a substitute for the burning of natural gas to accomplish this upgrade reduces natural gas consumption by $\sim 54 \mathrm{mscfd}$ and reduces $\mathrm{CO}_{2}$ emissions by $\sim 2,900$ tons per day.
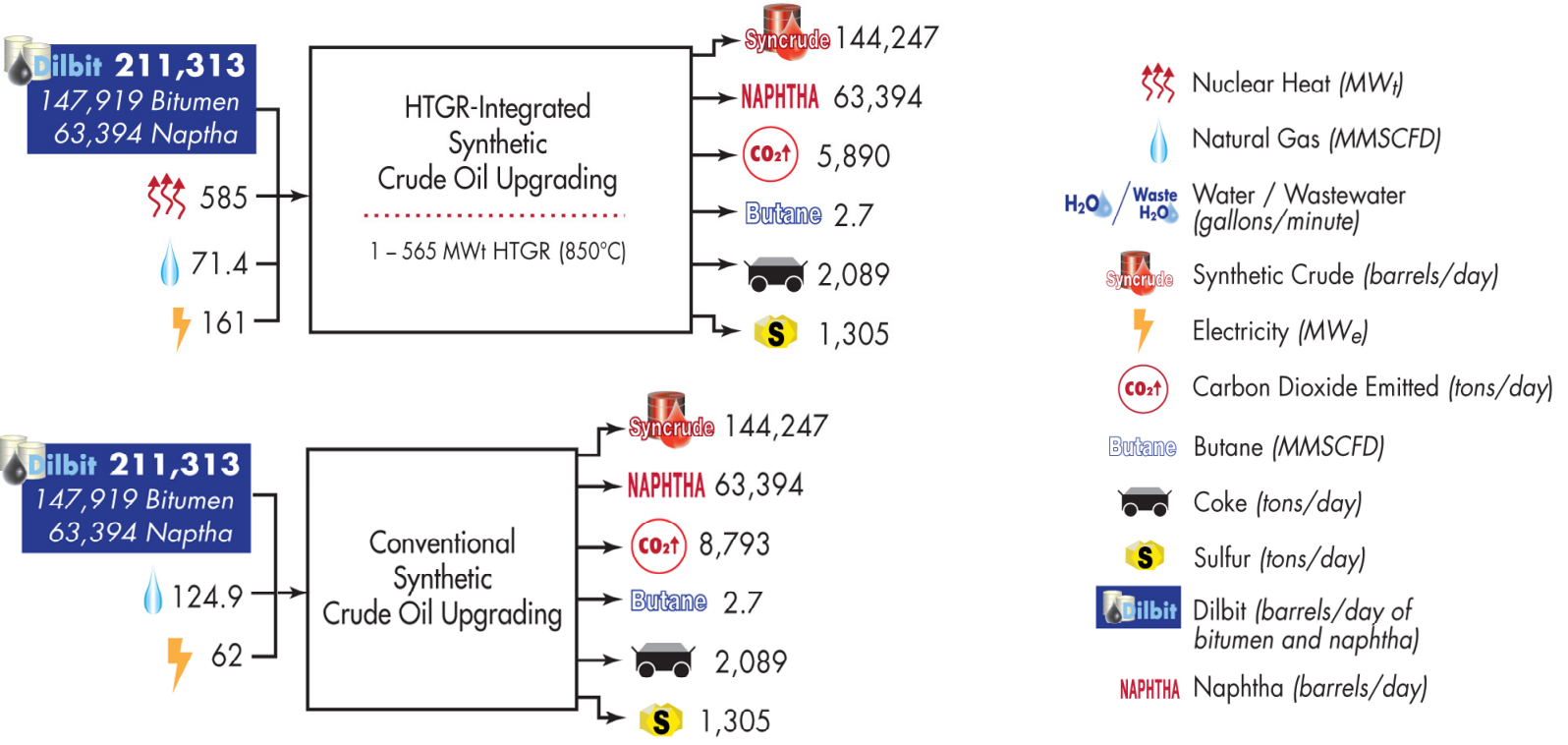

Figure 10. Mass and energy balance for conventional and HTGR integrated bitumen upgrading processes [Source: TEV-704, R2].

\subsection{The Full HTGR Plant}

Figure 11 shows the total mass and energy balance using HTGR technology to recover and upgrade bitumen from oil sands. As shown a total of $\sim 3,000 \mathrm{MW}(\mathrm{t})$ of HTGR energy is required to recover and upgrade $\sim 150,000 \mathrm{bpd}$ of bitumen, producing $\sim 145,000 \mathrm{bpd}$ of premium synthetic crude. The HTGR plant includes four $600 \mathrm{MW}(\mathrm{t})$ modules operating at $770^{\circ} \mathrm{C}$ that supply the energy required for bitumen recovery and recovered water treatment and one $565 \mathrm{MW}(\mathrm{t})$ module operating at $850^{\circ} \mathrm{C}$ supplying energy for the bitumen upgrade.

Full deployment of this plant would reduce natural gas consumption by over $200 \mathrm{mscfd}$ and reduce $\mathrm{CO}_{2}$ emissions by 13,000 metric tons per day. 


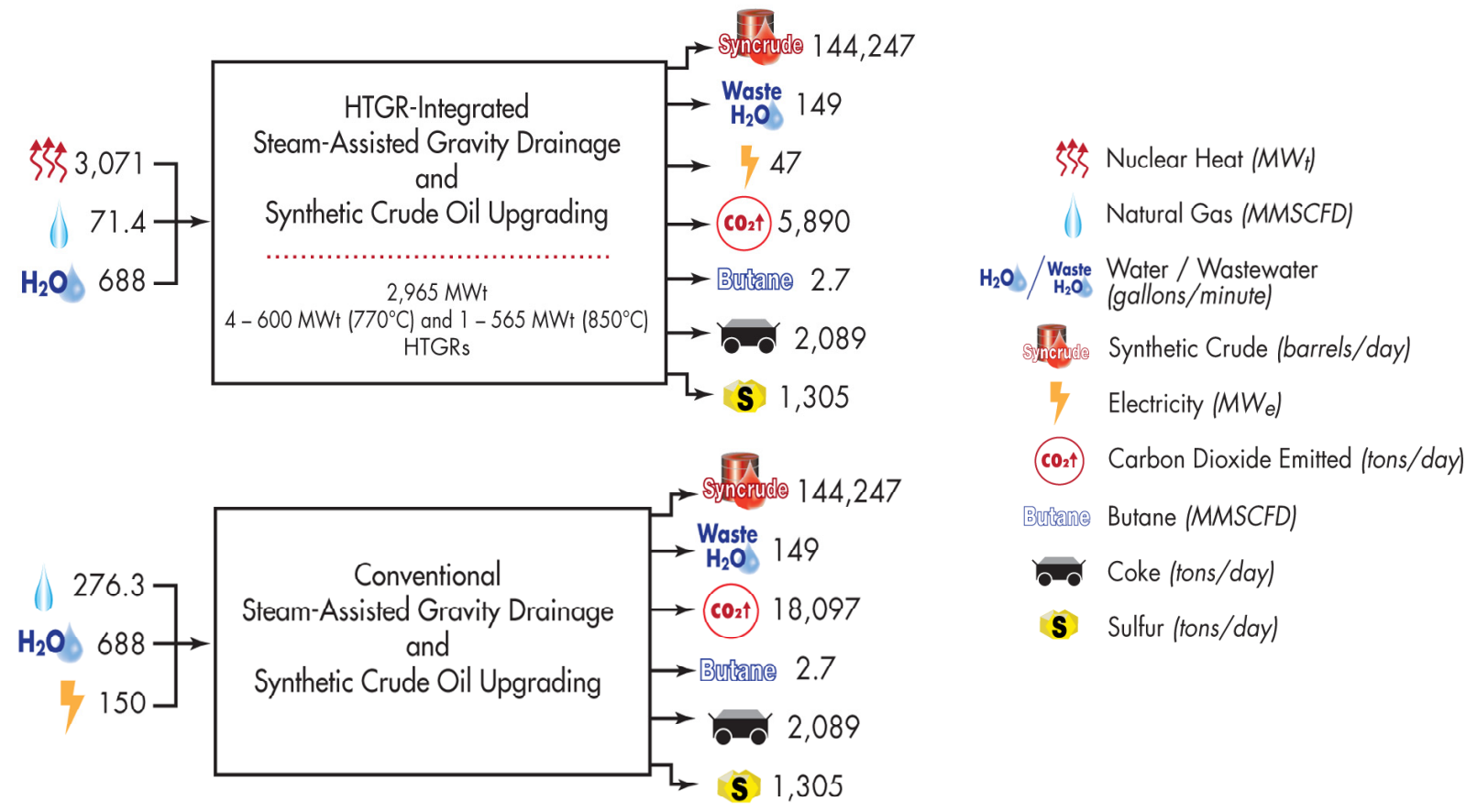

Figure 11. Comparison of conventional and HTGR integrated mass and energy balance for recovering and upgrading bitumen extracted from oil sands.

Figure 12 summarizes the distribution of energy among the processes. Note that of the $272 \mathrm{MW}(\mathrm{e})$ generated by the HTGR plant, $47 \mathrm{MW}(\mathrm{e})$ is available for distribution on the regional grid for general oil sands operations and domestic loads.

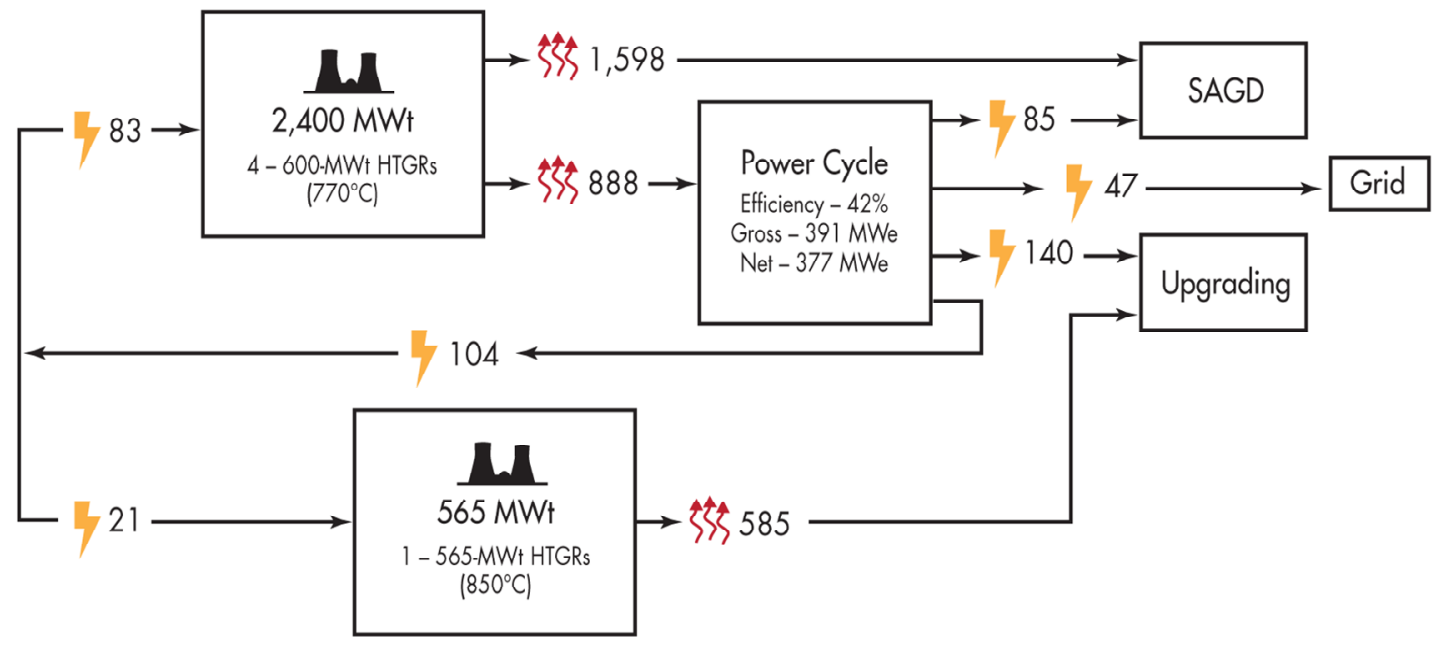
W $\mathrm{HTGR}(\mathrm{s})$
35 Nuclear Heat $\left(M W_{t}\right)$
Electricity $\left(M W_{e}\right)$

Figure 12. Distribution of energy supplied by the HTGR central energy supply plant. 


\section{PRELIMINARY ECONOMICS}

This section describes the business model on which the economic evaluations are based, the bases for the cost estimates for the HTGR plant, the financial factors used in the analysis, and the resulting price of energy.

\subsection{Potential Business Model}

Figure 13 depicts the business model on which the economics are based. Multiple approaches could be used in configuring this business model. For example, the energy from the HTGR facility could be delivered "over the fence" to the off-takers, the off-takers could own the facility and factor the cost of operating the facility into the cost of the products, or there could be some combination of these. For the purposes of this evaluation the HTGR plant is assumed to be a separable entity from the OSPs and the upgrading facilities and will be supplying energy to these entities "over the fence."

The owner(s) of the HTGR plant would enter into long term energy supply agreements with the OSPs and the upgrading facility. If the plant is also going to supply electricity on the regional grid, or for export, contracts will also be executed for these purposes. To achieve the required internal rate of return on investment, these agreements need to have provisions to support full use of the HTGR plant energy at high capacity factor over the lifetime of the plant. Typically, energy supply contracts will only extend for several years. They will contain clauses for price adjustments over this period (e.g., to account for inflationary factors) and provisions for continuation. It is important that such contracts between the central energy supply facility and the OSPs and upgrading facility provide adequate incentives for continuing these contracts over the life of the plant. This is necessary because nuclear plants have high capital costs but very low operating costs. During the economic recovery period, capital recovery makes up $\sim 70 \%$ of the operating costs. This contrasts with natural gas plants where fuel costs can account for up to $70 \%$ of the operating costs over this period. Achieving the required internal rate of return on investment in the nuclear plant, therefore, relies on long term operation at near full capacity factors.

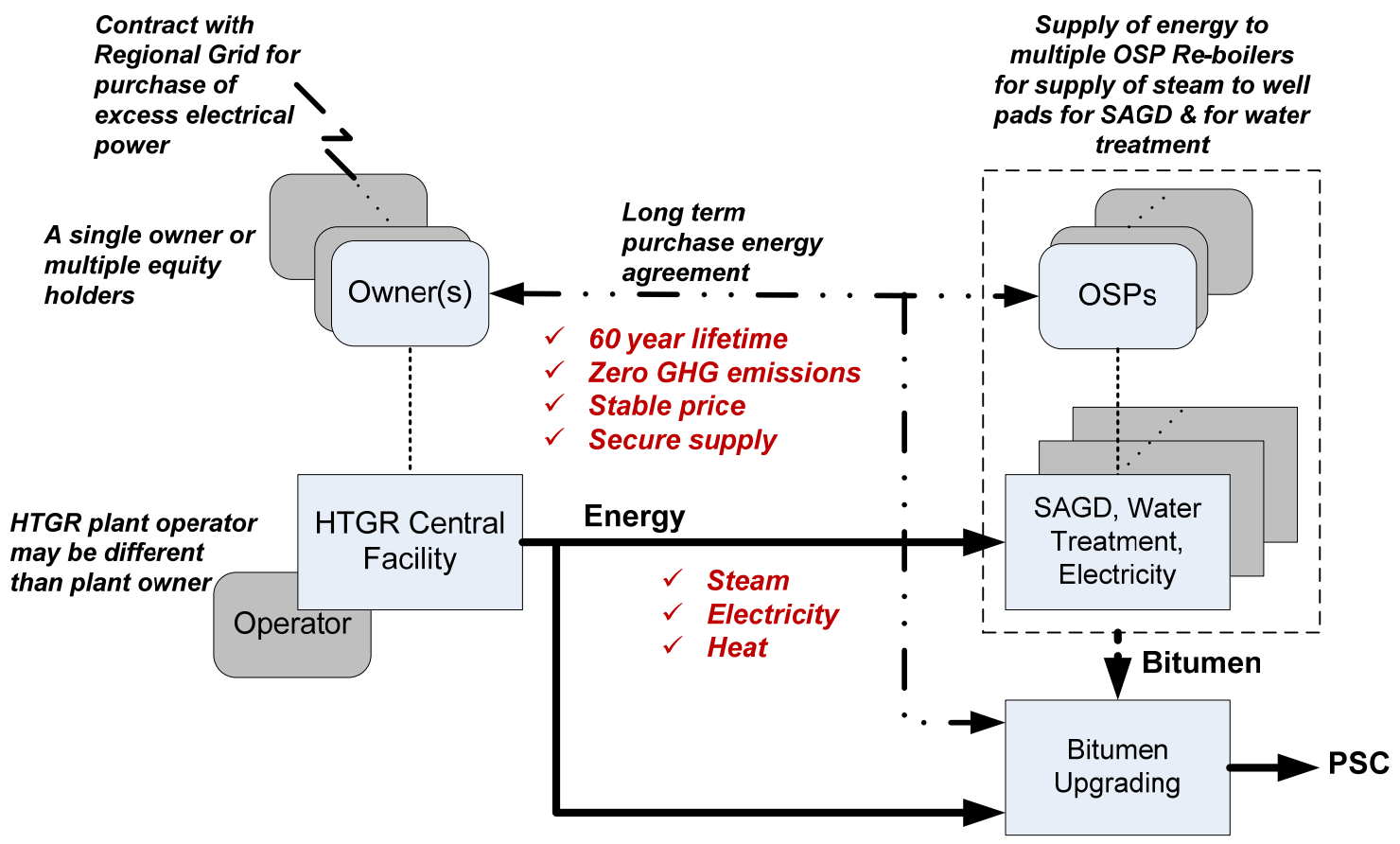

Figure 13. Central energy supply facility business model. 


\subsection{Costs}

Capital costs for the central energy supply facility project include the equipment, material, and labor to construct the five HTGR nuclear heat supply system (NHSS) modules, steam turbine generator systems, steam distribution systems, including piping to the OSP reboilers and upgrading facility, and electrical switchgear and transmission and distribution equipment to transport electricity to the OSPs and the upgrading facility and to interface with the existing regional grid. Table 1 summarizes the estimated costs for each of these items.

Table 1. Summary of capital costs estimate for the HTGR central energy facility.

\begin{tabular}{|c|c|c|c|}
\hline Item & $\begin{array}{l}\text { Cost* } \\
\text { \$U.S. millions }\end{array}$ & Component & Basis \\
\hline $\begin{array}{l}\text { NHSS Modules } \\
\left(770^{\circ} \mathrm{C}\right)\end{array}$ & $\$ 5,820$ & $\begin{array}{l}\text { Four } 600 \mathrm{MW}(\mathrm{t}) \mathrm{NHSS} \text { modules } \\
\text { operating at } 770^{\circ} \mathrm{C}\end{array}$ & $\begin{array}{l}\text { NGNP Project Cost } \\
\text { Correlations, } \$ 2,425 / \mathrm{KW}(\mathrm{t})\end{array}$ \\
\hline $\begin{array}{l}\text { NHSS Module } \\
\left(850^{\circ} \mathrm{C}\right)\end{array}$ & $\$ 1,460$ & $\begin{array}{l}\text { One } 565 \mathrm{MW}(\mathrm{t}) \mathrm{NHSS} \text { module } \\
\text { operating at } 850^{\circ} \mathrm{C}\end{array}$ & $\begin{array}{l}\text { NGNP Project Cost } \\
\text { Correlations, } \$ 2,584 / \mathrm{KW}(\mathrm{t})\end{array}$ \\
\hline $\begin{array}{l}\text { Steam Turbine } \\
\text { Generators }\end{array}$ & $\$ 620$ & $\begin{array}{l}\text { Two } 200 \text { MW(e) Subcritical } \\
\text { Rankine Cycle Steam Turbine } \\
\text { Generators }\end{array}$ & $\begin{array}{l}\text { NGNP Project Cost } \\
\text { Correlations, } \$ 1,550 / \mathrm{KW}(\mathrm{e})\end{array}$ \\
\hline $\begin{array}{l}\text { Steam Distribution to } \\
\text { OSPs for SAGD \& to } \\
\text { upgrading facility }\end{array}$ & $\$ 200$ & $\begin{array}{l}51 \mathrm{~km} \text { of } 24 \text {-inch steam piping } \\
\text { with insulation installed } \\
51 \mathrm{~km} \text { of condensate piping with } \\
\text { insulation }\end{array}$ & \\
\hline Electrical Distribution & $\$ 150$ & $\begin{array}{l}240 \mathrm{KV} \text { switchgear and } 51 \mathrm{~km} \text { of } \\
\text { distribution to OSPs and } \\
\text { upgrading facility }\end{array}$ & $\begin{array}{l}\text { See Reference } 12 \text { for } \\
\text { discussion of transmission } \\
\text { system design }\end{array}$ \\
\hline Total Capital Cost & $\$ 8,250$ & & \\
\hline
\end{tabular}

As shown, the HTGR NHSS modules and steam turbine generators account for over $95 \%$ of the total plant capital cost of $\sim \$ 8 \mathrm{~B}$. The capital costs for the NHSS modules are based on estimates developed by the NGNP Project since its initiation in 2007. They are a composite of specific plant cost estimates for HTGRs developed in the 1980s and 1990s by General Atomics for DOE, costs developed as part of preconceptual designs performed by the NGNP Project in 2007, cost updates as the designs and design requirements for the NHSS evolved from discussions with potential end users, and from bottoms up analysis of costs of major components such as large vessels. ${ }^{13}$ The cost estimates for the balance of equipment are based on conventional pricing data such as for electrical distribution, pipeline runs, etc.

All of the cost estimates were increased by a factor of $\sim 1.7$ to account for the remote location of the oil sands. The components of this factor are broken down in Table 2. 
Table 2. Breakdown of cost estimate factors, accounting for the remote oil sands location.

\begin{tabular}{|l|l|l|}
\hline \multicolumn{1}{|c|}{ Item } & Value & \multicolumn{1}{c|}{ Basis } \\
\hline $\begin{array}{l}\text { City Cost Index, for Fort McMurray, } \\
\text { Alberta }\end{array}$ & 1.09 & RSMeans 2010, commercial construction \\
\hline $\begin{array}{l}\text { Add 25\% for labor cost increase for } \\
\text { industrial/nuclear construction }\end{array}$ & 1.25 & Estimator judgment \\
\hline $\begin{array}{l}\text { Add 10\% for transportation of material and } \\
\text { equipment }\end{array}$ & 1.10 & Estimator judgment \\
\hline $\begin{array}{l}\text { Add 10\% for costs of special materials and } \\
\text { equipment }\end{array}$ & 1.10 & Estimator judgment \\
\hline Total location factor & 1.65 & \\
\hline
\end{tabular}

\subsection{Pricing of Energy}

The NGNP Project developed an economics modeling code to support evaluating the economic viability of HTGR integration with industrial processes. ${ }^{14}$ The model is based on discounted cash flow analysis, including all capital and operating costs for the HTGR plant and, where applicable, the industrial plant. The model is configured to permit: analysis of only the HTGR plant, providing energy in specified forms (e.g., steam, electricity, heat); or an integrated plant, including the HTGR as the principal energy supply, and the industrial processes producing a specific product(s) such as ammonia, synthetic transportation fuels, hydrogen, bitumen, and syncrude. The internal rate of return on owner equity and net present value are the principal parameters of interest calculated by the model.

The model includes high level designs of the plant configuration being analyzed (e.g., an HTGR plant only or a fully integrated industrial plant) that is used to develop capital and operating costs. Other model inputs include project schedule, construction schedule and cost profile, financial parameters, and project life. The model performs the calculation of internal rate of return on owner equity based on discounted cash flow over the life of the project using one of two optional approaches: the prices of the products are adjusted to achieve a required return, or the return is calculated for given product prices. For the economic analysis of the central energy supply facility, the former approach is used for the HTGR plant as a stand-alone entity (the prices of steam, electricity, and heat supplied to the OSPs and the upgrading facility are adjusted to achieve a required return). This section summarizes the results of this analysis.

The capital and operating costs for the oils sands project were summarized in the preceding section. Table 3 summarizes other key economic parameters of the analysis.

The following summarize the baseline per unit costs for steam, electricity, and heat calculated for the HTGR central energy supply facility described in the preceding sections using the parameters summarized in Table 3.

- Steam \$US 9/1000 lb

- Electricity \$US 96/MWe-hr

- Heat \$US 12.50/MMBtu 
Table 3. Key economic analysis parameters.

\begin{tabular}{|ll|}
\hline \multicolumn{1}{c|}{ Item } & \multicolumn{1}{c|}{ Value } \\
\hline Project start date & 2015 \\
Total construction time & 7 years \\
Project lifetime & 60 years \\
Required internal rate of return on owner equity & $10 \%$ \\
Debt to equity ratio & $80 \%$ \\
Interest during construction & $8 \%$ \\
Debt financing interest & $8 \%$ \\
Debt term & 20 years \\
Consolidated tax rate & $27.1 \%$ \\
Depreciation & MACRS 15 years \\
Inflation factor & $3 \%$ \\
Escalation factor & None \\
\hline
\end{tabular}

The price quoted for HTGR heat is approximately equivalent to the price for natural gas, if it were the energy source for steam, electricity, and heat generation in the central energy facility. The HTGR heat price is high compared with the current costs for natural gas used in the Alberta oil sands, which has been in the range $\$ 5$ to $\$ 6 / \mathrm{MMBtu}$ delivered. To be equivalent with the HTGR heat source, however, the efficiency of the natural gas boiler needs to be accounted for. Assuming an $83 \%$ boiler efficiency and a $\$ 5.50 / \mathrm{MMBtu}$ natural gas price the equivalent price of natural gas heat is $\$ 6.63 / \mathrm{MMBtu}(5.5 / 0.83)$. The HTGR heat price is still high compared with this equivalent natural gas price. However, this comparison does not include any adjustment for the potential costs associated with carbon emissions from firing of the natural gas. Figure 14 shows the effect of applying carbon credits to the price of the HTGR heat as a function of the cost of $\mathrm{CO}_{2}$ emissions in $\$ /$ ton. This shows that a carbon credit of $\sim \$ 120 /$ ton of $\mathrm{CO}_{2}$ emissions would bring the adjusted costs of the HTGR heat into the same range as the current equivalent natural gas costs in the oil sands. Such costs of carbon emissions could be encountered if government actions impose higher $\mathrm{CO}_{2}$ taxes or require capture and sequestration of $\mathrm{CO}_{2}$ emissions. Were this to occur with costs in the range of $\$ 120 /$ ton of $\mathrm{CO}_{2}$, the HTGR central energy facility is more economical.

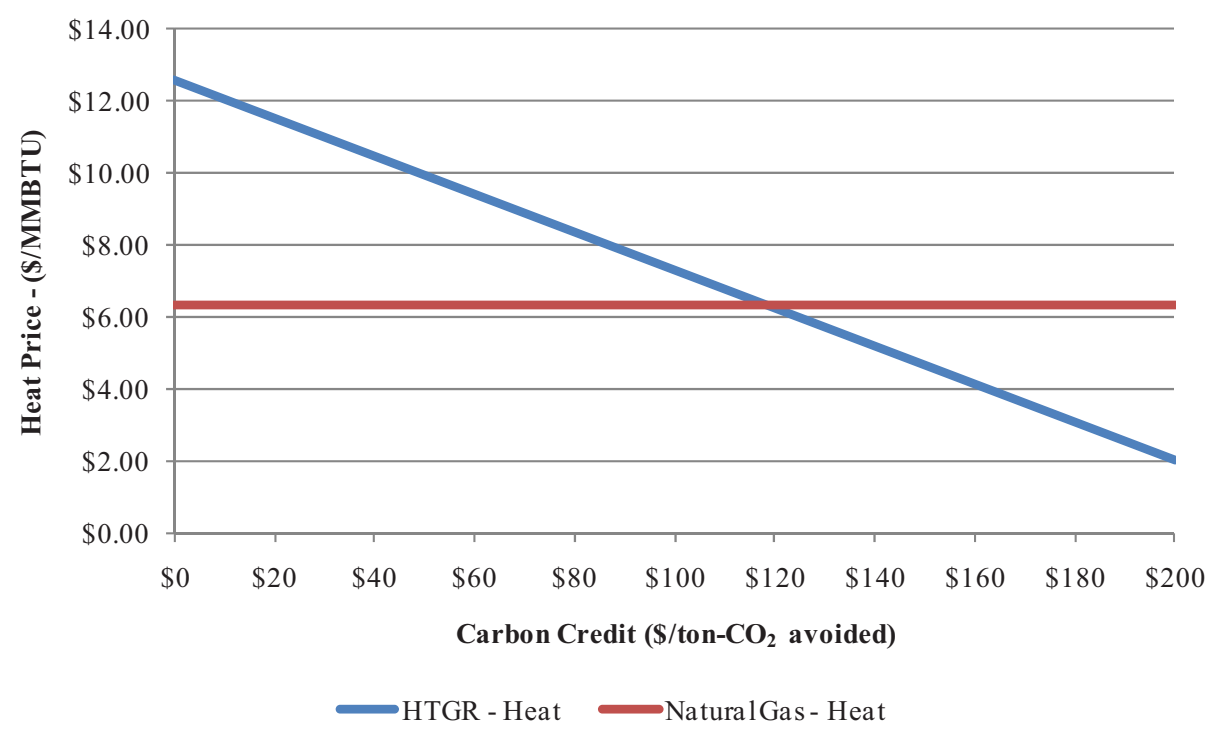

Figure 14. Effect of carbon credits on effective HTGR energy price for central energy facility [Source TEV-704]. 
An alternative analysis was performed to determine the price of energy if only the SAGD processes were supplied with steam and electricity from the central energy facility (the upgrading facility was not included). The prices rise about $6 \%$ as follows:

- Steam \$US 9.5/1000 lb

- Electricity \$US 102/MWe-hr

- Heat \$US 13/MMBtu

The NGNP Project is just entering the conceptual design stage. Accordingly, there is considerable uncertainty in the capital and operating costs for the HTGR. There is also considerable uncertainty in the financial and other parameters that will apply when the project will be implemented. Figures 15, 16, and 17 are tornado charts showing the effect of changes in key parameters on the prices of steam, electricity and heat. These figures show considerable influence from the cost adder for operation in the remote oil sands area, required internal rate of return, capital project cost, and interest rates on the baseline prices of steam, electricity, and heat. The OSPs and the upgrading facility would evaluate whether these are acceptable prices, considering the benefits of the HTGR central energy supply facility in providing reliable energy over the long term at a stable price with no greenhouse gas emissions. These evaluations would also consider the effect of potential carbon costs as depicted in Figure $14 .^{\mathrm{c}}$

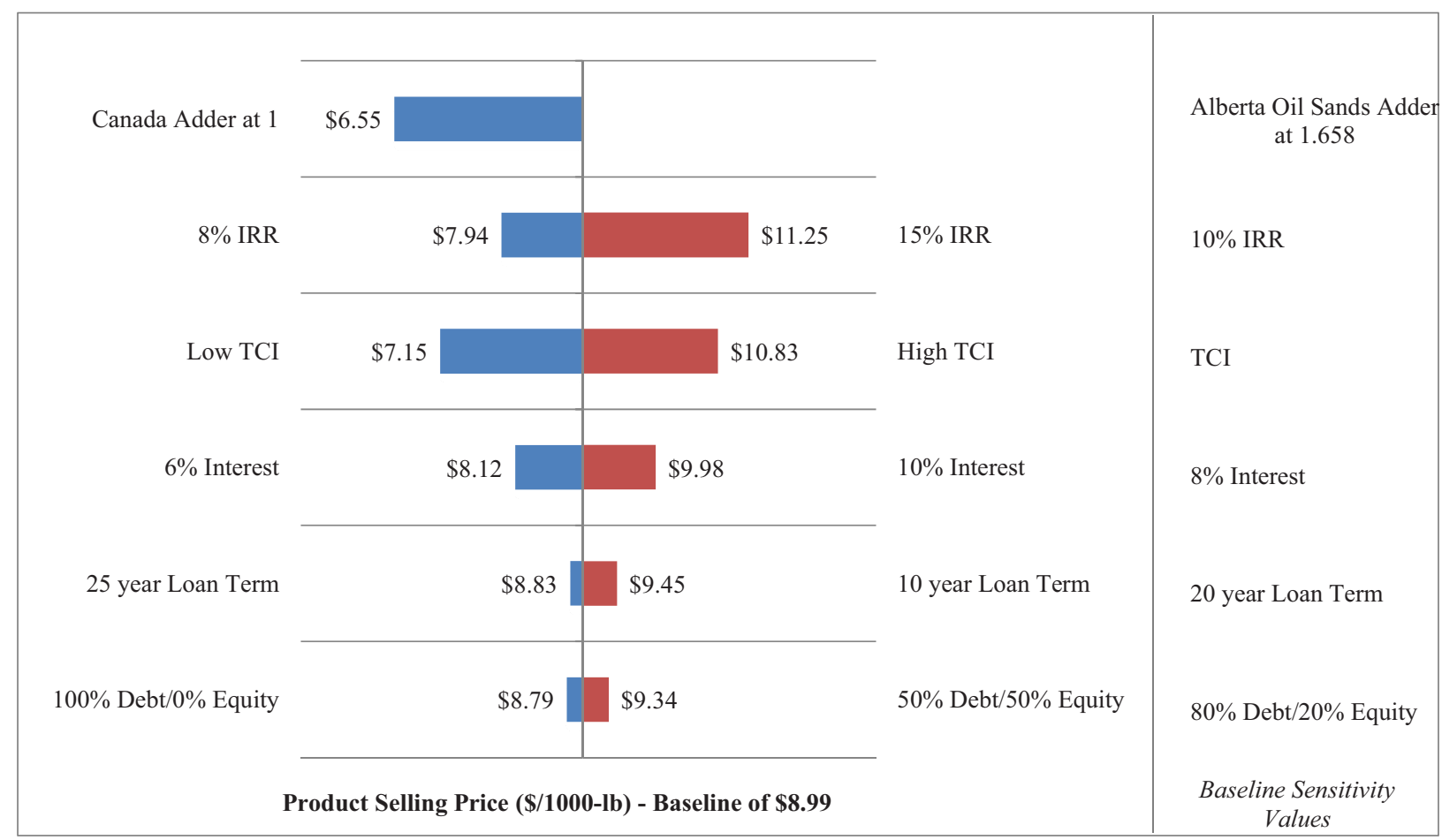

Figure 15. Effect of variations in key economic parameters on the price of steam.

c. All of the economic calculations summarized in this section were made using Excel files "PTAC_Rev_3 and Economics_PTAC_HTGR_Rev_4_Monte_Carlo Analysis 9-5-11.” 


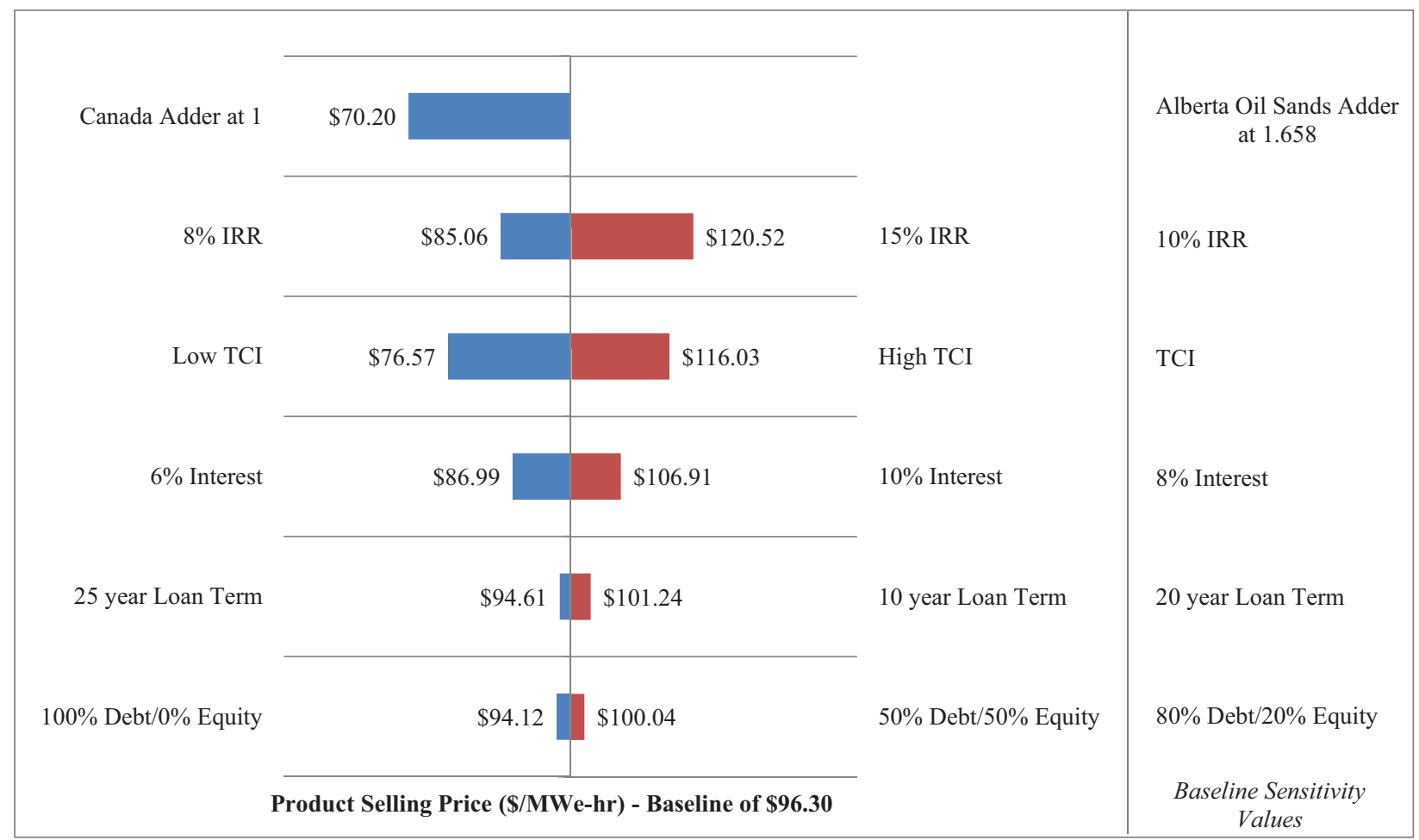

Figure 16. Effect of variations in key economic parameters on the price of electricity.

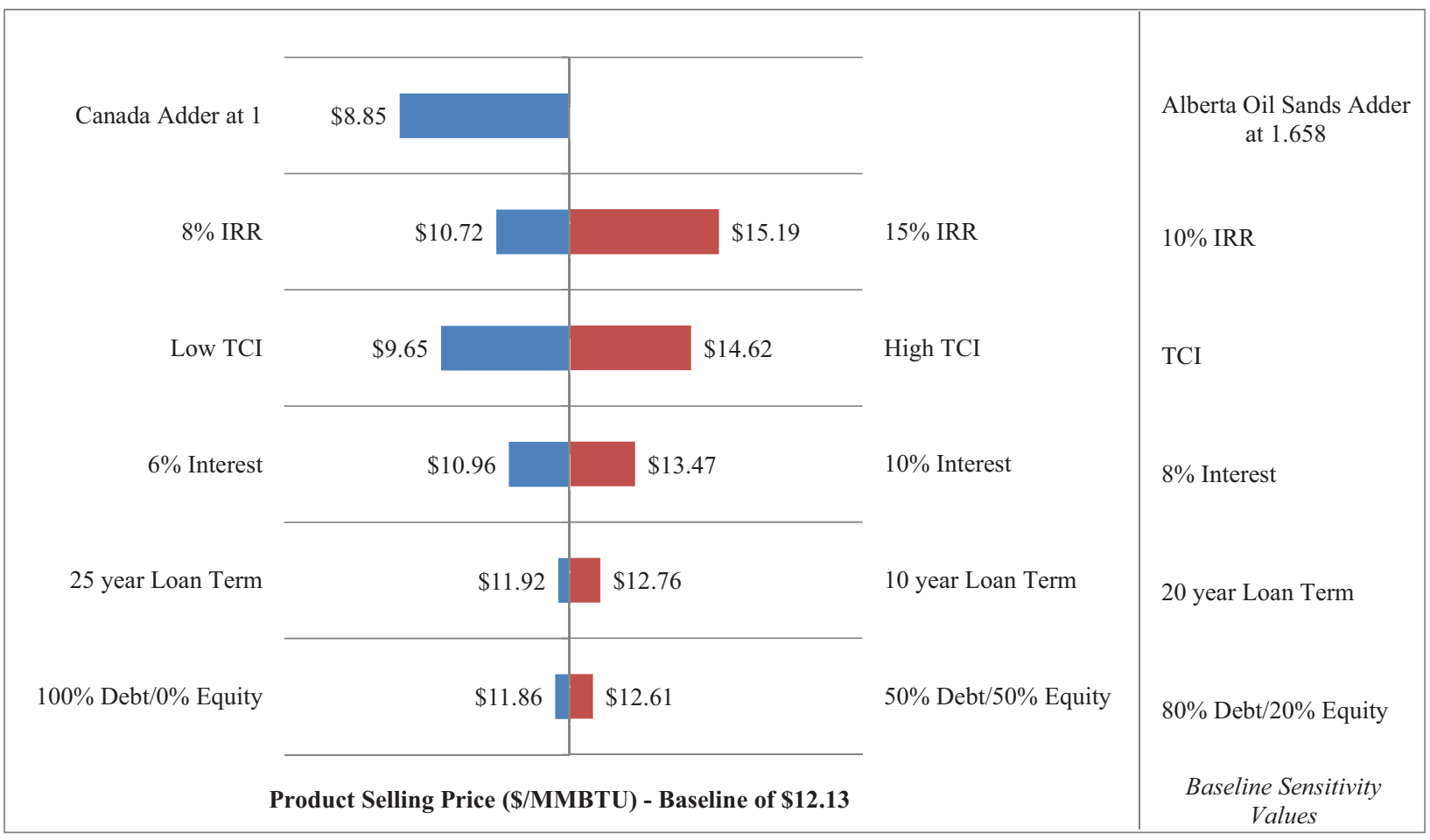

Figure 17. Effect of variations in key economic parameters on the price of heat.

These tornado charts illustrate the influence of individual parameters on the necessary pricing to meet the required internal rate of return. It is not appropriate to combine the variations shown on these charts. 
Figures 18, 19, and 20 show the combined effects of these variations in the form of probability distributions for electricity, steam and heat prices. These charts were developed using a 10,000 step Monte Carlo Simulation applying triangular distributions over the extremes identified for each parameter in Figures 15-17. Figures 18-20 also show the relevant statistics for each price. Note that the mean value is similar to that shown as the baseline value in Figures 15-17. The relatively large standard deviations reflect the large uncertainty in the values of the key parameters. As the design of the HTGR evolves these uncertainties will be reduced and more confidence developed in the economics of its application to this and other industrial applications.

Fore cast: ElecPrice

Cell: B2

Summary:

Entire range is from $\$ 51.89$ to $\$ 155.26$

Base case is $\$ 96.30$

After 10,000 trials, the std. error of the mean is $\$ 0.16$

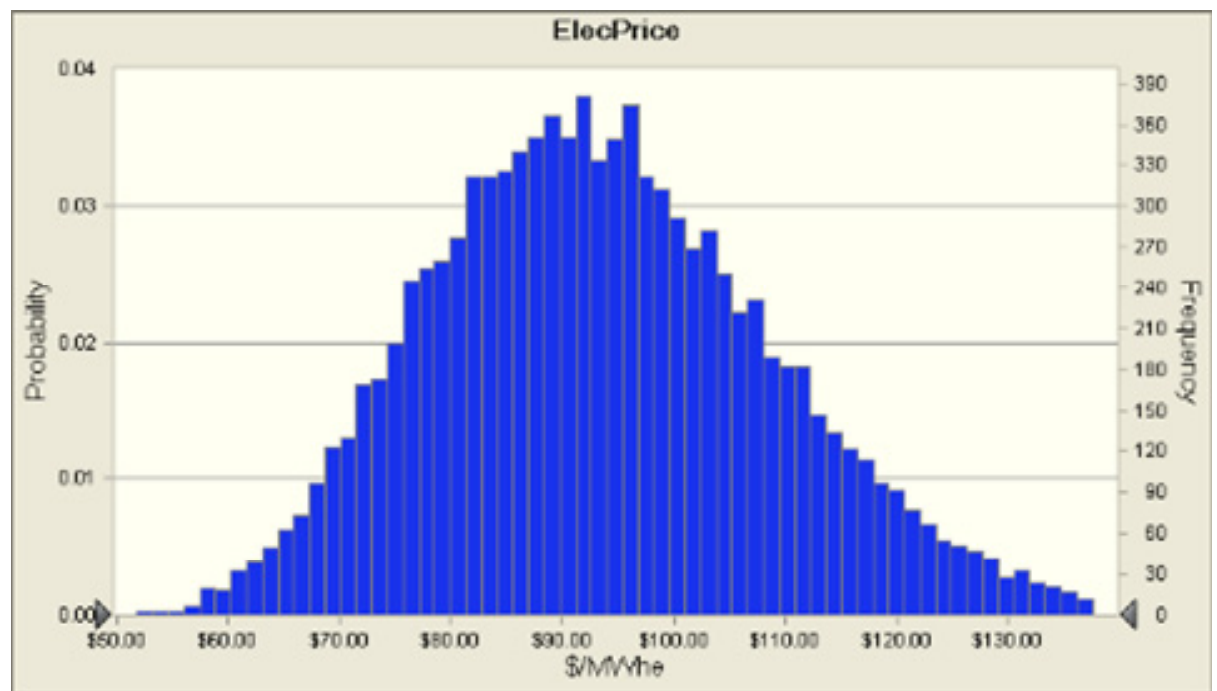

$\begin{array}{lr}\text { Statistics: } & \text { Forecast values } \\ \text { Trials } & 10,000 \\ \text { Mean } & \$ 93.78 \\ \text { Median } & \$ 92.68 \\ \text { Mode } & -- \\ \text { Standard Deviation } & \$ 15.63 \\ \text { Variance } & \$ 244.30 \\ \text { Skewness } & 0.3753 \\ \text { Kurtosis } & 3.01 \\ \text { Coeff. of Variability } & 0.1667 \\ \text { Minimum } & \$ 51.89 \\ \text { Maximum } & \$ 155.26 \\ \text { Range Width } & \$ 103.37 \\ \text { Mean Std. Error } & \$ 0.16\end{array}$

Figure 18. Electricity price, \$/MWhe-probability distribution and statistics. 
Summary:

Entire range is from 4.84 to 14.49

Base case is 8.99

After 10,000 trials, the std. error of the mean is 0.01

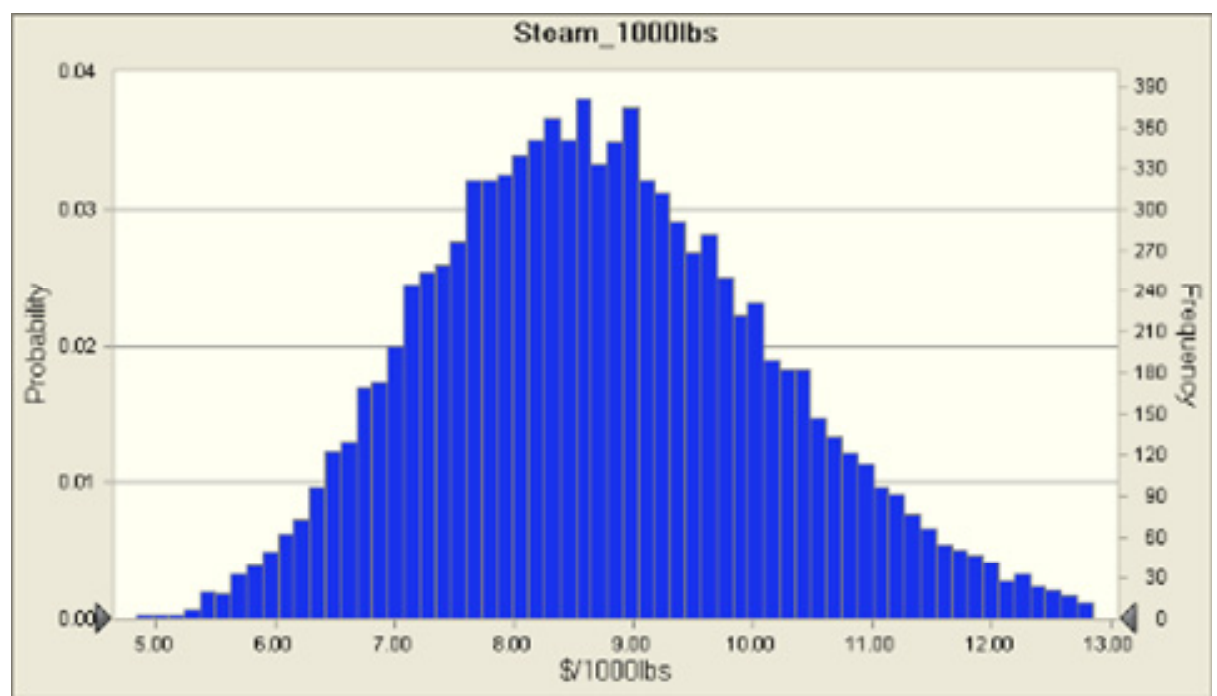

$\begin{array}{lr}\text { Statistics: } & \text { Forecast values } \\ \text { Trials } & 10,000 \\ \text { Mean } & 8.75 \\ \text { Median } & 8.65 \\ \text { Mode } & -- \\ \text { Standard Deviation } & 1.46 \\ \text { Variance } & 2.13 \\ \text { Skewness } & 0.3753 \\ \text { Kurtosis } & 3.01 \\ \text { Coeff. of Variability } & 0.1667 \\ \text { Minimum } & 4.84 \\ \text { Maximum } & 14.49 \\ \text { Range Width } & 9.65 \\ \text { Mean Std. Error } & 0.01\end{array}$

Figure 19. Steam price, $\$ / 1000 \mathrm{lb}$ probability distribution and statistics. 
Summary:

Entire range is from 6.54 to 19.56

Base case is 12.13

After 10,000 trials, the std. error of the mean is 0.02

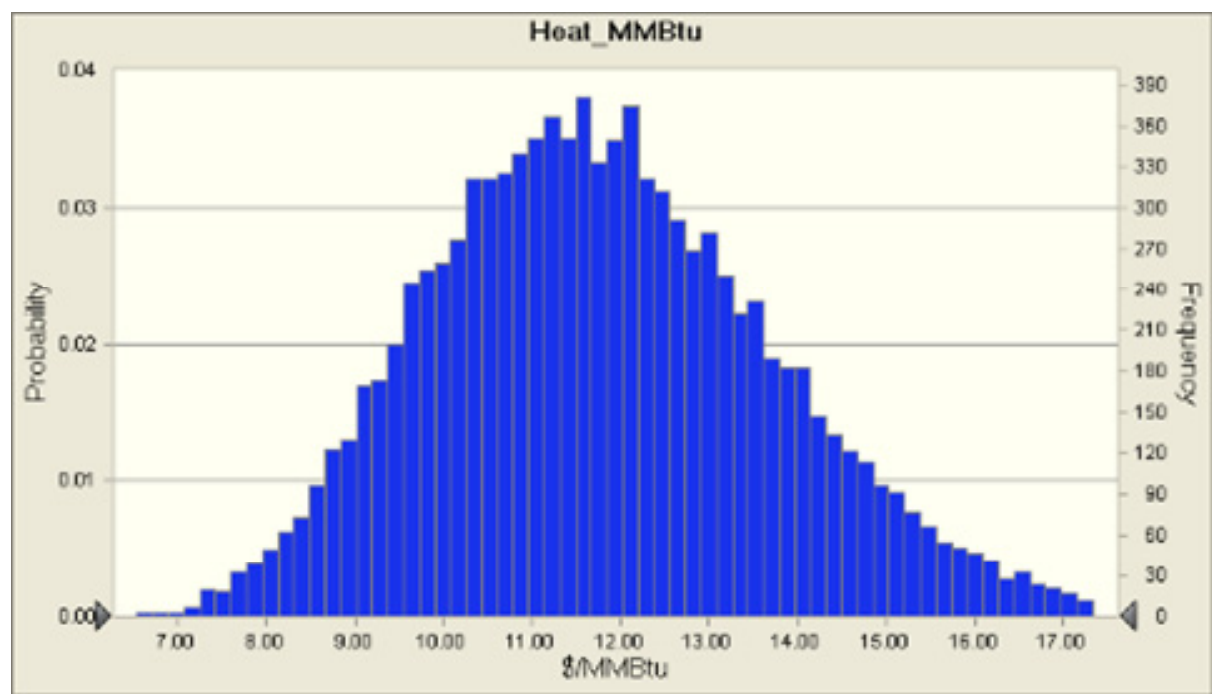

$\begin{array}{lr}\text { Statistics: } & \text { Forecast values } \\ \text { Trials } & 10,000 \\ \text { Mean } & 11.82 \\ \text { Median } & 11.68 \\ \text { Mode } & -- \\ \text { Standard Deviation } & 1.97 \\ \text { Variance } & 3.88 \\ \text { Skewness } & 0.3753 \\ \text { Kurtosis } & 3.01 \\ \text { Coeff. of Variability } & 0.1667 \\ \text { Minimum } & 6.54 \\ \text { Maximum } & 19.56 \\ \text { Range Width } & 13.02 \\ \text { Mean Std. Error } & 0.02\end{array}$

Figure 20. Steam price, $\$ 11000 \mathrm{lb}$-probability distribution and statistics. 


\section{SUMMARY OF RESULTS AND CONCLUSIONS}

A conceptual design has been developed for an HTGR-based central energy supply facility that can supply the energy needs to recover $\sim 150,000$ bpd of bitumen from the Alberta, Canada oil sands using the SAGD process and for upgrading of that bitumen to produce $\sim 145,000$ bpd of premium synthetic crude. The central facility is designed to provide steam and electricity to multiple oil sands producers located up to $25 \mathrm{~km}$ from the central energy facility for simultaneous operation of 20 well pads with 10 well pairs per pad. The energy supply to the oil sands producers is sufficient to support bitumen extraction using SAGD, separation and treatment of water recovered with the bitumen, dilution of the bitumen, and transport of the bitumen to the upgrading facility. The energy is supplied from the central energy facility in the forms of electricity and high temperature steam. The high temperature steam is applied to a steam reboiler at the oil sands producer facility that supplies the steam for operation of the well pads. This reboiler would replace the gas fired steam generators currently used at the OSP facilities. This is the only major modification that would be required at the OSP facility to receive energy from the central facility.

A full bitumen upgrading approach that produces premium synthetic crude has been selected for the upgrading facility. This approach is more amenable to integration with HTGR technology and adds the most value to the bitumen recovered from the oil sands. In this application the HTGR supplies electricity, heat, and hydrogen, all of which are readily available products from the HTGR technology. This process is also judged to reflect the current thinking of oil sands producers.

The central energy facility project includes installation of at least five HTGR nuclear heat supply modules with a total plant rating of $\sim 3,000 \mathrm{MW}(\mathrm{t})$, several kilometers of steam and condensate piping, and electrical distribution lines to multiple oil sand producer facilities and the upgrading facility as shown in Figure 4. The central facility would have a high capital cost but low operating, maintenance, and fuel costs and a long lifetime. In the beginning of operation, the annual costs are dominated by the capital recovery and financing costs; about $70 \%$ of the annual costs. Once the financings costs no longer apply (e.g., after the first 20 years of operation), the annual costs of operating the plant drop considerably. The plant can, therefore, provide energy at a reasonable price for a long period of time; 60 years or more. To take advantage of the long lifetime of the facility, a notional deployment of the energy supply to the oils sands producer facilities was developed that results in coverage of $\sim 43,000$ hectares of oil sands over the 60 year period as shown in Figure 5. Using estimates of recovery of bitumen reserves over this area consistent with oil sands producer practices, this plant would be capable of supporting recovery of 2.6 billion bbl of bitumen over its lifetime. If this bitumen were fully upgraded 2.5 billion barrels of premium synthetic crude would be produced.

Scoping analyses of the economics of the central energy facility were performed assuming the facility as a standalone entity supplying steam, electricity, and heat for the oil sands processes. This also includes supply of electricity on the oil sands electrical grid for support of domestic and other general electrical demands. The economic analyses are based on adjusting the prices for the steam, electricity, and heat to achieve a required internal rate of return on owner equity for the project. The calculations use a discounted cash flow analysis model that includes capital and operating costs and revenues using benchmark values for financial parameters such as debt-to-equity ratio, interest rates and financing terms, tax rates, and inflation rates. Because there was considerable uncertainty in the costs and appropriate financial parameters for the analysis, parametric and statistical analyses were performed to assess the effect of variations in the key economic factors on the results. These analyses provide expected ranges around a baseline value of the price as follows:

- $\quad$ Steam $\quad \$ U S 9 \pm 2.2 / 1000 \mathrm{lb}$

- Electricity \$US 96 $\pm 24 / \mathrm{MWe}-\mathrm{hr}$

- Heat \$US $12 \pm 3 / \mathrm{MMBtu}$ 
The heat price can be compared with the price of natural gas if natural gas were used in place of the HTGR plant in the central energy supply facility. The heat price is considerably higher than the current natural gas prices in the oil sands; $\$ 5$ to $\$ 6 / \mathrm{MMBtu}$. These baseline prices, however, do not reflect any adjustments for potential costs of $\mathrm{CO}_{2}$ emissions that would result from burning the natural gas. The economic analyses show that a $\$ 120$ /ton charge for $\mathrm{CO}_{2}$ emissions (whether as a tax on the burning of natural gas or as a cost for $\mathrm{CO}_{2}$ capture and sequestration) would result in an effective price for the HTGR heat equal to the current energy price in the oil sands. Current taxes on $\mathrm{CO}_{2}$ emissions in the oils sands are low, $<\$ 20 /$ ton. If the costs of $\mathrm{CO}_{2}$ emissions were to increase to the $\$ 120 /$ ton or higher range because of governmental actions, the HTGR provides a viable economic alternative.

The application of an HTGR based central energy facility addresses long term issues associated with recovering and upgrading bitumen; principally greenhouse gas emissions and price instability associated with the large quantities of natural gas used currently as the energy supply. The central energy facility design developed in this evaluation addresses these issues by:

- Reducing natural gas consumption by $205 \mathrm{mscfd}$ (4.5 trillion cubic feet over the life of the plant)

- Reducing $\mathrm{CO}_{2}$ emissions by $\sim 13$ thousand tons per day ( 285 million tons over the life of the plant).

This approach to energy supply effectively insulates the oil sands producers over the long term from the potential imposition of carbon costs or issues with natural gas supply.

This facility would also provide a reliable source of energy for at least 60 years at a price that would be affected only by normal inflationary effects on the costs of operating materials and labor.

This plant was designed to cover an area of $\sim 43,000$ hectares and recover up to $50 \%$ of the bitumen reserves in this area. The Alberta oil sands cover an area of $\sim 14$ million hectares with an estimated 1.7 trillion barrels of recoverable bitumen. There is, therefore, considerable prospect for application of several of these central energy facilities that would further reduce the consumption of natural gas and $\mathrm{CO}_{2}$ emissions. As an example, a prior NGNP Project study posits that deployment of six central energy supply facilities similar to that described herein would be sufficient to support $25 \%$ of the expansion in in-situ recovery of bitumen and upgrading of that bitumen projected in the Alberta oil sands in the time frame 2025 to $2050 .^{4}$ 


\section{REFERENCES}

1. Public Law 109-58, Energy Policy Act of 2005, $109^{\text {th }}$ Congress of the United States, August 8, 2005.

2. L. Nelson, A. Gribik, V. Maio, M. McKellar, M. Patterson, and R. Wood, Integration of High Temperature Gas-Cooled Reactors into Industrial Process Applications, INL/EXT-09-16942, Revision 2, Idaho National Laboratory, May 2010.

3. L. Nelson, A. Gandrik, M. McKellar, E. Robertson, M. Patterson, and R. Wood, Integration of High Temperature Gas-Cooled Reactors into Selected Industrial Process Applications, INL/EXT-1123008, Idaho National Laboratory, August 2011.

4. Idaho National Laboratory, High Temperature Gas-cooled Reactor Projected Markets and Preliminary Economics, INL/EXT-10-19037, Revision 1, August 2011.

5 Idaho National Laboratory, Basis for NGNP Reactor Design Down Selection, INL/EXT-10-19565, March 2011.

6 Selection of Nuclear Energy Technology for Alberta Oil Sands Applications, September 2011.

7. Murray R. Gray, Tutorial on Upgrading of Oilsands Bitumen, http://www.ualberta.ca/ gray/Links\%20\&\%20Docs/Web\%20Upgrading\%20Tutorial.pdf, Website visited January 24, 2001 and February 1, 2011.

8. TEV-1351, An Analysis of Fluids for the Transport of Heat with HTGR-Integrated Steam Assisted Gravity Drainage, Idaho National Laboratory, September 2011.

9. TEV-704, HTGR-Integrated Oil Sands Recovery using Steam Assisted Gravity Drainage, Revision 2, Idaho National Laboratory, September 2011.

10. E-mail, Kurt Uhrich response to questions, PTAC/AES, August 2011.

11. TEV-1147, HTGR-Integrated Bitumen Upgrading Analysis, Idaho National Laboratory, April 2011.

12 Oil Sands Transmission System Design, September 2011.

13. TEV-1196, Assessment of High Temperature Gas-cooled Reactor (HTGR) Capital and Operating Costs, Idaho National Laboratory, April 2011.

14. TEV-988, Sensitivity of HTGR Heat and Power Production to Reactor Outlet Temperature, Economic Analysis, Idaho National Laboratory, July 2011. 